\title{
The secondary formation of organosulfates under interactions between biogenic emissions and anthropogenic pollutants in summer in Beijing
}

\author{
Yujue Wang $^{1}$, Min Hu${ }^{1,5}$, Song Guo ${ }^{1}$, Yuchen Wang ${ }^{3}$, Jing Zheng ${ }^{1}$, Yudong Yang ${ }^{1}$, Wenfei Zhu ${ }^{6}$, Rongzhi Tang ${ }^{1}$, \\ Xiao Li ${ }^{1}$, Ying Liu ${ }^{1,5}$, Michael Le Breton ${ }^{2}$, Zhuofei Du ${ }^{1}$, Dongjie Shang ${ }^{1}$, Yusheng Wu ${ }^{1}$, Zhijun Wu ${ }^{1}$, Yu Song ${ }^{1}$, \\ Shengrong $\mathrm{Lou}^{6}$, Mattias Hallquist ${ }^{2}$, and Jianzhen $\mathbf{Y u}^{3,4}$ \\ ${ }^{1}$ State Key Joint Laboratory of Environmental Simulation and Pollution Control, College of Environmental \\ Sciences and Engineering, Peking University, Beijing 100871, China \\ ${ }^{2}$ Department of Chemistry and Molecular Biology, University of Gothenburg, Gothenburg, Sweden \\ ${ }^{3}$ Environmental Science Programs, Hong Kong University of Science \& Technology, Hong Kong, China \\ ${ }^{4}$ Department of Chemistry, Hong Kong University of Science \& Technology, Hong Kong, China \\ ${ }^{5}$ Beijing Innovation Center for Engineering Sciences and Advanced Technology, Peking University, Beijing 100871, China \\ ${ }^{6}$ Shanghai Academy of Environmental Sciences, Shanghai 200233, China
}

Correspondence: Min Hu (minhu@pku.edu.cn) and Jianzhen Yu (jian.yu@ust.hk)

Received: 12 March 2018 - Discussion started: 29 March 2018

Revised: 11 July 2018 - Accepted: 14 July 2018 - Published: 26 July 2018

\begin{abstract}
Organosulfates (OSs) with ambiguous formation mechanisms are a potential source of "missing secondary organic aerosol (SOA)" in current atmospheric models. In this study, we chemically characterized OSs and nitrooxyOSs (NOSs) formed under the influence of biogenic emissions and anthropogenic pollutants (e.g., $\mathrm{NO}_{x}, \mathrm{SO}_{4}^{2-}$ ) in summer in Beijing. An ultrahigh-resolution mass spectrometer equipped with an electrospray ionization source was applied to examine the overall molecular composition of $\mathrm{S}$-containing organics. The number and intensities of Scontaining organics, the majority of which could be assigned as OSs and NOSs, increased significantly during pollution episodes, which indicated their importance for SOA accumulation. To further investigate the distribution and formation of OSs and NOSs, high-performance liquid chromatography coupled with mass spectrometry was employed to quantify 10 OSs and 3 NOS species. The total concentrations of quantified OSs and NOSs were 41.4 and $13.8 \mathrm{ng} \mathrm{m}^{-3}$, respectively. Glycolic acid sulfate was the most abundant species among all the quantified species, followed by monoterpene NOSs $\left(\mathrm{C}_{10} \mathrm{H}_{16} \mathrm{NO}_{7} \mathrm{~S}^{-}\right)$. The total concentration of three isoprene OSs was $14.8 \mathrm{ng} \mathrm{m}^{-3}$ and the isoprene OSs formed via the $\mathrm{HO}_{2}$ channel were higher than those formed via the $\mathrm{NO} / \mathrm{NO}_{2}$ channel. The OS concentration coincided with the
\end{abstract}

increase in acidic sulfate aerosols, aerosol acidity, and liquid water content (LWC), indicating the acid-catalyzed aqueousphase formation of OSs in the presence of acidic sulfate aerosols. When sulfate dominated the accumulation of secondary inorganic aerosols (SIAs; sulfate, nitrate, and ammonium; $\mathrm{SO}_{4}^{2-}$ / SIA >0.5), OS formation would obviously be promoted as the increasing of acidic sulfate aerosols, aerosol LWC, and acidity $(\mathrm{pH}<2.8)$. Otherwise, acid-catalyzed OS formation would be limited by lower aerosol acidity when nitrate dominated the SIA accumulation. The nighttime enhancement of monoterpene NOSs suggested their formation via the nighttime $\mathrm{NO}_{3}$-initiated oxidation of monoterpene under high- $\mathrm{NO}_{x}$ conditions. However, isoprene NOSs are presumed to form via acid-catalyzed chemistry or reactive uptake of oxidation products of isoprene. This study provides direct observational evidence and highlights the secondary formation of OSs and NOSs via the interaction between biogenic precursors and anthropogenic pollutants $\left(\mathrm{NO}_{x}, \mathrm{SO}_{2}\right.$, and $\left.\mathrm{SO}_{4}^{2-}\right)$. The results imply that future reduction in anthropogenic emissions can help to reduce the biogenic SOA burden in Beijing or other areas impacted by both biogenic emissions and anthropogenic pollutants. 


\section{Introduction}

Secondary organic aerosol (SOA), formed by the atmospheric oxidation of volatile organic compounds (VOCs), accounts for a large fraction of organic aerosol (OA) on the global scale (Jimenez et al., 2009; Guo et al., 2014). However, current models usually underestimate (Kroll and Seinfeld, 2008; Hallquist et al., 2009) or predict the SOA concentration with large uncertainties (Jimenez et al., 2009; Kiehl, 2007; Shrivastava et al., 2017) in the ambient atmosphere. Thus, it is important to elucidate potential missing groups of compounds or formation mechanisms. Organosulfates (OSs), commonly formed via the interaction between VOC precursors and acidic sulfate seed particles, could be a potential source of "missing SOA" in current atmospheric models (Surratt et al., 2010). OSs have been observed in various ambient atmospheres, including urban, rural, suburban, forest, and remote environments (Lin et al., 2012; Meade et al., 2016; Stone et al., 2012; Riva et al., 2015; Brüggemann et al., 2017), which could represent 2-30\% of OA (Hawkins et al., 2010; Stone et al., 2012; Frossard et al., 2011; Tolocka and Turpin, 2012; Surratt et al., 2008; Liao et al., 2015).

Many prior chamber experiments revealed the precursors and formation mechanisms of OSs (Surratt et al., 2007, 2008, 2010; Liggio and Li, 2006; Chan et al., 2011; Shalamzari et al., 2014, 2016; Zhang et al., 2012); however, the atmospheric relevance of these remain unclear. Various biogenic VOC (BVOC) precursors have been reported, including isoprene (Hatch et al., 2011; Surratt et al., 2010), monoterpenes (Surratt et al., 2008), sesquiterpenes (Chan et al., 2011), pinonaldehyde (Liggio and $\mathrm{Li}, 2006$ ), unsaturated aldehydes (Shalamzari et al., 2014, 2016), and 2-methyl-3-buten2-ol (Zhang et al., 2012). OSs originating from isoprene are some of the most studied compounds and could be among the most abundant OA in some areas (Liao et al., 2015; Chan et al., 2010; Surratt et al., 2010; Lin et al., 2013a; Worton et al., 2013). Isoprene OSs usually form through ring-opening epoxide chemistry catalyzed by acidic sulfate aerosols (Worton et al., 2013; Froyd et al., 2010; Paulot et al., 2009). OSs were also proposed to form by the reactive uptake of VOCs or their oxidation products that involve the sulfate radicals (Nozière et al., 2010; Schindelka et al., 2013). The sulfate esterification of alcohols could also be a pathway leading to OS formation, while Minerath et al. (2018) predicted that this mechanism was kinetically insignificant under ambient tropospheric conditions. However, this prediction was based on laboratory bulk solution-phase experiments and the applicability to the liquid phase on particles suspended in the air is unconfirmed. Nitrooxy-organosulfates (NOSs) were observed to form via the nighttime $\mathrm{NO}_{3}$-initiated oxidation of VOC precursors (e.g., monoterpene), followed by alcohol sulfate esterification (Iinuma et al., 2007; Surratt et al., 2008). Organic nitrate $\left(\mathrm{R}-\mathrm{ONO}_{2}\right)$ could also act as a precursor to OSs through the nucleophilic substitution of nitrate by sulfate (Hu et al., 2011; Darer et al., 2011).
Both aerosol acidity and liquid water content (LWC) are key variables influencing the OS formation processes. OS formation could only happen in the presence of sulfate aerosols, which is enhanced by increased aerosol acidity through the acid-catalyzed reactive uptake and multiphase reactions of oxidation products (Riva et al., 2016c; Surratt et al., 2010; Lal et al., 2012; Riedel et al., 2015). Previous studies also demonstrated the importance of aqueous-phase or heterogeneous reactions for OS formation (Lal et al., 2012; McNeill et al., 2012; McNeill, 2015; Riedel et al., 2015). On the one hand, increased LWC would decrease the aerosol viscosity, which favors the exchange of organics or other gas molecules into the particles, mass diffusion of reactants, and heterogeneous chemical reactions within the particles (Vaden et al., 2011; Booth et al., 2014; Renbaum-Wolff et al., 2013; Shrestha et al., 2015; Zhang et al., 2015), thereby enhancing OS formation. On the other hand, more LWC would lead to increased pH due to dilution. For example, Riva et al. (2016) and Duporte et al. (2016) found that OS formation decreased with higher $\mathrm{RH}$, which was attributed to increased $\mathrm{pH}$ as a result of higher LWC (Duporte et al., 2016; Riva et al., 2016c).

To get a comprehensive understanding of the characteristics and formation of OSs in the ambient atmosphere, it is desirable to simultaneously identify and quantify particulate OSs on the molecular level. Soft ionization techniques coupled with an ultrahigh-resolution mass spectrometer (UHRMS) have been widely applied to identify various and numerous organics, including OS species, in ambient aerosols or chamber studies (Lin et al., 2012; Blair et al., 2017; Tao et al., 2014; Wang et al., 2016). UHRMS is a powerful analytical tool in gaining an overall characterization of OSs; however, the quantification capability is limited without pre-separation. High-performance liquid chromatography coupled with a mass spectrometer (HPLC-MS) is suitable for the separation and quantification of different OS compounds. However, one noted limitation is a lack of commercially available authentic standards. As a result, surrogate standards are often used for quantification (He et al., 2014; Riva et al., 2015; Zhang et al., 2012), which adds uncertainty to the concentrations (Wang et al., 2017d). Recently, a few research groups quantified some OS species using synthetic authentic standards (e.g., hydroxyacetone sulfate, glycolic acid sulfate, lactic acid sulfate, methyltetrol sulfate, aromatic OSs, $\alpha$ - and $\beta$-pinene OS, limonene OS, and limonaketone OS; Hettiyadura et al., 2017, 2015; Olson et al., 2011; Wang et al., 2017d; Ma et al., 2014; Budisulistiorini et al., 2015; Staudt et al., 2014), which was very important for understanding the variation and formation of OSs in ambient aerosols.

Missing knowledge of formation mechanisms, the complexities of ambient aerosol composition and oxidation conditions, and the lack of commercially available standards all hinder us from understanding the formation and fate of OSs in the ambient atmosphere. Few field studies have been conducted in urban areas dominated by anthropogenic pollutants (e.g., $\mathrm{NO}_{x}, \mathrm{SO}_{4}^{2-}$ ). Observations are lacking to illustrate how 
severe anthropogenic pollutants could influence OS formation under different physical environmental conditions. This work reports a comprehensive characterization of particulate OSs in summertime Beijing, a location under the influence of both biogenic and severe anthropogenic sources. This study provides direct observational evidence for gaining insights into OS formation. Orbitrap MS coupled with a soft ionization source was used to identify the overall molecular composition of S-containing organics. HPLC-MS was then applied to quantify some OSs and NOS species in ambient aerosols using newly synthesized authentic standards and surrogate standards. Previously proposed formation pathways of OS or NOS (e.g., acid-catalyzed aqueous-phase chemistry, nighttime $\mathrm{NO}_{3}$ chemistry) were considered, and the influence of different environmental conditions or factors on formation were comprehensively elaborated. It has been suggested that both aqueous-phase chemistry and nighttime $\mathrm{NO}_{3}$ chemistry play important roles in the heavy haze over Beijing (Wu et al., 2018; Wang et al., 2017a, b). Using OSs and NOSs as examples, this work illustrates SOA formation via acidcatalyzed aqueous-phase chemistry, nighttime $\mathrm{NO}_{3}$ chemistry under the interaction between abundant anthropogenic pollutants, and biogenic emissions.

\section{Methods}

\subsection{Sample collection}

This study was a part of the bilateral Sweden-China framework research program "Photochemical smog in China: formation, transformation, impact and abatement strategies", focusing on SOA formation under the influence of anthropogenic pollutants (Hallquist et al., 2016). An intensive field campaign was conducted at Changping $\left(40.14^{\circ} \mathrm{N}\right.$, $116.11^{\circ} \mathrm{E}$ ), a regional site $38 \mathrm{~km}$ northeast of the Beijing urban area, China. The campaign was conducted from 15 May to 23 June 2016 when the site was influenced by high biogenic emissions from vegetation in the nearby mountains and anthropogenic pollutants from the nearby villages and Beijing urban areas (Tang et al., 2018). During 17 May-5 June, the average concentrations of isoprene, monoterpenes, benzene, toluene, and $\mathrm{NO}_{x}$ were $297,83,441,619$ pptv, and $22.7 \mathrm{ppb}$, respectively.

Ambient aerosols were collected from 16 May to 5 June. $\mathrm{PM}_{2.5}$ (particles with an aerodynamic diameter less than $2.5 \mu \mathrm{m}$ ) samples were collected on prebaked quartz fiber filters (Whatman Inc.) and Teflon filters (Whatman Inc.) using a high-volume sampler (TH-1000C, Tianhong, China) and a four-channel sampler (TH-16A, Tianhong, China). The sampling flow rates were $1.05 \mathrm{~m}^{3} \mathrm{~min}^{-1}$ and $16.7 \mathrm{~L} \mathrm{~min}^{-1}$, respectively. The daytime samples were collected from 08:30 to 17:30 LT (UTC + 8) and nighttime ones from 18:00 to 08:00 LT the next morning. Field blank samples were collected by placing filters in the samplers with the pump off for
30 min. The period 20 May-3 June will be discussed in this study.

\subsection{Orbitrap MS analysis}

An Exactive Plus Orbitrap MS (Thermo Scientific Inc., Bremen, Germany) equipped with a heated electrospray ionization (ESI) source was used to identify the overall molecular composition of OSs. Details on the extraction and data analysis have been described in Wang et al. (2017c). Briefly, a portion of filter was extracted with ultrapure water in an ultrasonic bath for $40 \mathrm{~min}$ and the extracts were filtered with a $0.45 \mu \mathrm{m}$ pore size PTFE syringe filter (Gelman Sciences). The filter portion size was adjusted to yield $\sim 200 \mu \mathrm{g}$ OC in each extract in order to decrease the variation of ion suppression arising from varying coexisting organic components. The influence of ion suppression is illustrated in Text S1 in the Supplement. The extract sample was then loaded onto a solid-phase extraction (SPE) cartridge (DSC-18, Sigma Aldrich, USA) to remove inorganic ions and low-molecularweight (MW) organic acids (Lin et al., 2010), followed by elution with methanol. The methanol eluate was dried under a gentle stream of $\mathrm{N}_{2}$ and redissolved in acetonitrilewater $(1: 1)$ solvent for Orbitrap MS analysis. Some selected OS species of low-MW (e.g., isoprene-derived OSs such as $\mathrm{C}_{4} \mathrm{H}_{7} \mathrm{O}_{7} \mathrm{~S}^{-}, \mathrm{C}_{5} \mathrm{H}_{7} \mathrm{O}_{7} \mathrm{~S}^{-}$, and $\mathrm{C}_{5} \mathrm{H}_{11} \mathrm{O}_{7} \mathrm{~S}^{-}$) would be removed by the SPE clean-up procedure and thus not detected by the direct infusion Orbitrap MS analysis (see Sect. 3.1). We note that these OS species were detected by HPLC-MS in the sample extracts to which no SPE pretreatment procedure was applied (see Sect. 2.3). This phenomenon was also reported in previous studies (Gao et al., 2006; Surratt et al., 2007).

The Orbitrap MS was operated in negative mode. The mass calibration was conducted using a standard mixture of N-butylamine, caffeine, MAFA, sodium dodecyl sulfate, sodium taurocholate, and Ultramark 1621, with the scan range set to $90-900 \mathrm{~m} / z$. The Orbitrap MS had a mass resolving power of 140000 at $m / z=200$. Each sample was analyzed three times with at least 100 full-scan spectra acquired in each analysis. The recorded mass spectra were processed and exported using Xcalibur software (v2.2, Thermo Scientific). Peaks with a signal-to-noise ratio $\geq 10$ were exported. All the mathematically possible formulas for each ion were calculated with a mass tolerance of $2 \mathrm{ppm}$. Each exported molecular formula was allowed to contain certain elements and limited by several conservative rules (Wang et al., 2017c). Elements ${ }^{12} \mathrm{C},{ }^{1} \mathrm{H},{ }^{16} \mathrm{O},{ }^{14} \mathrm{~N},{ }^{32} \mathrm{~S}$, and ${ }^{13} \mathrm{C}$ were allowed in the molecular formula calculations. The $\mathrm{H} / \mathrm{C}$, $\mathrm{O} / \mathrm{C}, \mathrm{N} / \mathrm{C}$, and $\mathrm{S} / \mathrm{C}$ ratios were limited to $0.3-3.0,0$ $3.0,0-0.5$, and $0-2.0$. The assigned formulas were also restrained by the double bond equivalent values and the nitrogen rule for even electron ions. More details about the molecular formula assignment have been introduced in Wang et al. (2017c). The background spectra were obtained by an- 
alyzing the corresponding field blank sample following the same procedure. Peaks were eliminated from the list if their intensities were lower than 10 times those in the blank sample.

\subsection{Quantification of OSs and NOSs using HPLC-MS}

An aliquot of $25 \mathrm{~cm}^{2}$ was removed from each filter sample and extracted in an ultrasonic bath three times using 3,2, and $1 \mathrm{~mL}$ methanol consecutively, each time for $30 \mathrm{~min}$. The extracts were then filtered through a $0.25 \mu \mathrm{m}$ polytetrafluoroethylene (PTFE) syringe filter (Pall Life Sciences), combined, evaporated to dryness under a gentle stream of highpurity nitrogen, and redissolved in $50 \mu \mathrm{L}$ methanol-water $(1$ : 1) containing $1 \mathrm{ppm} \mathrm{D}_{17}$-octyl sulfate as an internal standard. The solution was centrifuged and the supernatant was used for analysis using the Agilent $1260 \mathrm{LC}$ system (Palo Alto, CA) coupled to a QTRAP 4500 (AB Sciex, Toronto, Ontario, Canada) mass spectrometer. The LC-MS was equipped with an ESI source operated in negative mode. The optimized MS conditions and details of the method have been described in our previous study (Wang et al., 2017d). Chromatographic separation was performed on an Acquity UPLC HSS T3 column $(2.1 \mathrm{~mm} \times 100 \mathrm{~mm}, 1.8 \mu \mathrm{m}$ particle size; Waters, USA) with a guard column (HSS T3, $1.8 \mu \mathrm{m})$. The mobile eluents were (A) water containing $0.1 \%$ acetic acid $(v / v)$ and (B) methanol $(v / v)$ containing $0.1 \%$ acetic acid at a flow rate of $0.19 \mathrm{~mL} \mathrm{~min}$. The gradient elution was set as follows: the composition started with $1 \% \mathrm{~B}$ for $2.7 \mathrm{~min}$, increased to $54 \% \mathrm{~B}$ within $12.5 \mathrm{~min}$ and held for $1.0 \mathrm{~min}$, then increased to $90 \% \mathrm{~B}$ within $7.5 \mathrm{~min}$ and held for $0.2 \mathrm{~min}$, and finally decreased to $1 \% \mathrm{~B}$ within $1.8 \mathrm{~min}$ and held for $17.3 \mathrm{~min}$ until the column was equilibrated. The column temperature was kept at $45^{\circ} \mathrm{C}$ and the injection volume was $5.0 \mu \mathrm{L}$.

The quantified OS and NOS species are listed in Table 1. The monoterpene NOSs $\left(\mathrm{C}_{10} \mathrm{H}_{16} \mathrm{NO}_{7} \mathrm{~S}^{-}\right.$and $\left.\mathrm{C}_{9} \mathrm{H}_{14} \mathrm{NO}_{8} \mathrm{~S}^{-}\right)$ were quantified using the $[\mathrm{M}-\mathrm{H}]^{-}$ions in the extracted ion chromatogram (EIC) and other species were quantified in multiple-reaction monitoring (MRM) mode. OSs and NOSs were quantified using authentic standards or surrogates with similar molecular structures (Table 1). Lactic acid sulfate (LAS) and glycolic acid sulfate (GAS) were prepared according to Olson et al. (2011). The purities of LAS and GAS are $8 \%$ and $15 \%$, determined by ${ }^{1} \mathrm{H}$ NMR analysis using dichloroacetic acid as an internal standard, and the recoveries are $89.5 \%$ and $94.9 \%$, respectively. Four monoterpene-derived OS standards were synthesized and the details are given in Wang et al. (2017). The purity of the four monoterpene OS standards are higher than $99 \%$ and the recoveries are $80.5 \%-93.5 \%$ (Table S1 in the Supplement). OSs with similar carbon chain structures usually have similar MS responses (Wang et al., 2017d). Lactic acid sulfate was employed as a surrogate standard to quantify isoprene OSs due to their similar structures and retention times (Table 1). $\alpha$-Pinene OS and limonaketone OS were respec- tively used to quantify monoterpene NOSs $\mathrm{C}_{10} \mathrm{H}_{16} \mathrm{NO}_{7} \mathrm{~S}^{-}$ and $\mathrm{C}_{9} \mathrm{H}_{14} \mathrm{NO}_{8} \mathrm{~S}^{-}$due to the similar carbon structures (Table 1). For the molecule with isomers, quantification was performed by summing up the peak areas of the isomers, which were treated as one species (e.g., monoterpene NOSs with $[\mathrm{M}-\mathrm{H}]^{-}$at $m / z 294$ were treated as one NOS species).

\subsection{Other online and offline measurements}

A high-resolution time-of-flight aerosol mass spectrometer (AMS) was employed to measure the chemical composition of $\mathrm{PM}_{1}$. The operation procedures and data analysis have been described in Zheng et al. (2017). VOCs were measured by a proton-transfer-reaction mass spectrometer (PTRMS). Meteorological parameters, including relative humidity (RH), temperature, wind direction, and wind speed (WS), were continuously monitored by a weather station (Met One Instruments Inc.) during the campaign. Organic carbon (OC) was analyzed using a thermal-optical carbon analyzer (Sunset Laboratory). The organic matter (OM) concentration was calculated by multiplying OC by 1.6 (Turpin and Lim, 2001). Water-soluble inorganic ions and low-MW organic acids (e.g., oxalic acid) were quantified by an ion chromatograph (IC, DIONEX, ICS2500/ICS2000) following procedures described in Guo et al. (2010). After performing quality assurance and quality control for IC measurements, the data (ions, $\mathrm{pH}, \mathrm{LWC}$ ) derived from IC measurements in the daytime samples of 26 and 29 May were excluded in the following analysis. Gaseous $\mathrm{NH}_{3}$ was measured using an $\mathrm{NH}_{3}$ analyzer (G2103, Picarro, California, USA; Huo et al., 2015). Aqueous-phase $\left[\mathrm{H}^{+}\right]$and LWC were then calculated with the ISORROPIA-II thermodynamic model. ISORROPIA-II was operated in forward mode, assuming the particles are "metastable" (Hennigan et al., 2015; Weber et al., 2016; Guo et al., 2015). The input parameters included ambient $\mathrm{RH}$, temperature, particle-phase inorganic species $\left(\mathrm{SO}_{4}^{2-}\right.$, $\mathrm{NO}_{3}^{-}, \mathrm{Cl}^{-}, \mathrm{NH}_{4}^{+}, \mathrm{K}^{+}, \mathrm{Na}^{+}, \mathrm{Ca}^{2+}, \mathrm{Mg}^{2+}$ ), and gaseous $\mathrm{NH}_{3}$. The thermodynamic calculations were validated by the good agreement between measured and predicted gaseous $\mathrm{NH}_{3}$ (slope $=0.99, R^{2}=0.97$; see Text S2 for details). The contribution of organics to LWC was not considered in this study. Our previous study in Beijing has suggested that LWC associated with organic species was insignificant $(<6 \%)$ compared to that of secondary inorganic aerosols (Wu et al., 2018; see Fig. S3 in the Supplement for the comparison between LWC with or without water associated with organic compounds). Previous studies also suggested that the predicted aerosol acidity or $\mathrm{pH}$ without consideration of organic water could also be sufficient for discussing aqueous SOA chemistry in this study due to the minor effect on aerosol $\mathrm{pH}$ (0.15-0.23; Guo et al., 2015). 
Table 1. Organosulfates and nitrooxy-organosulfates quantified by HPLC-MS.

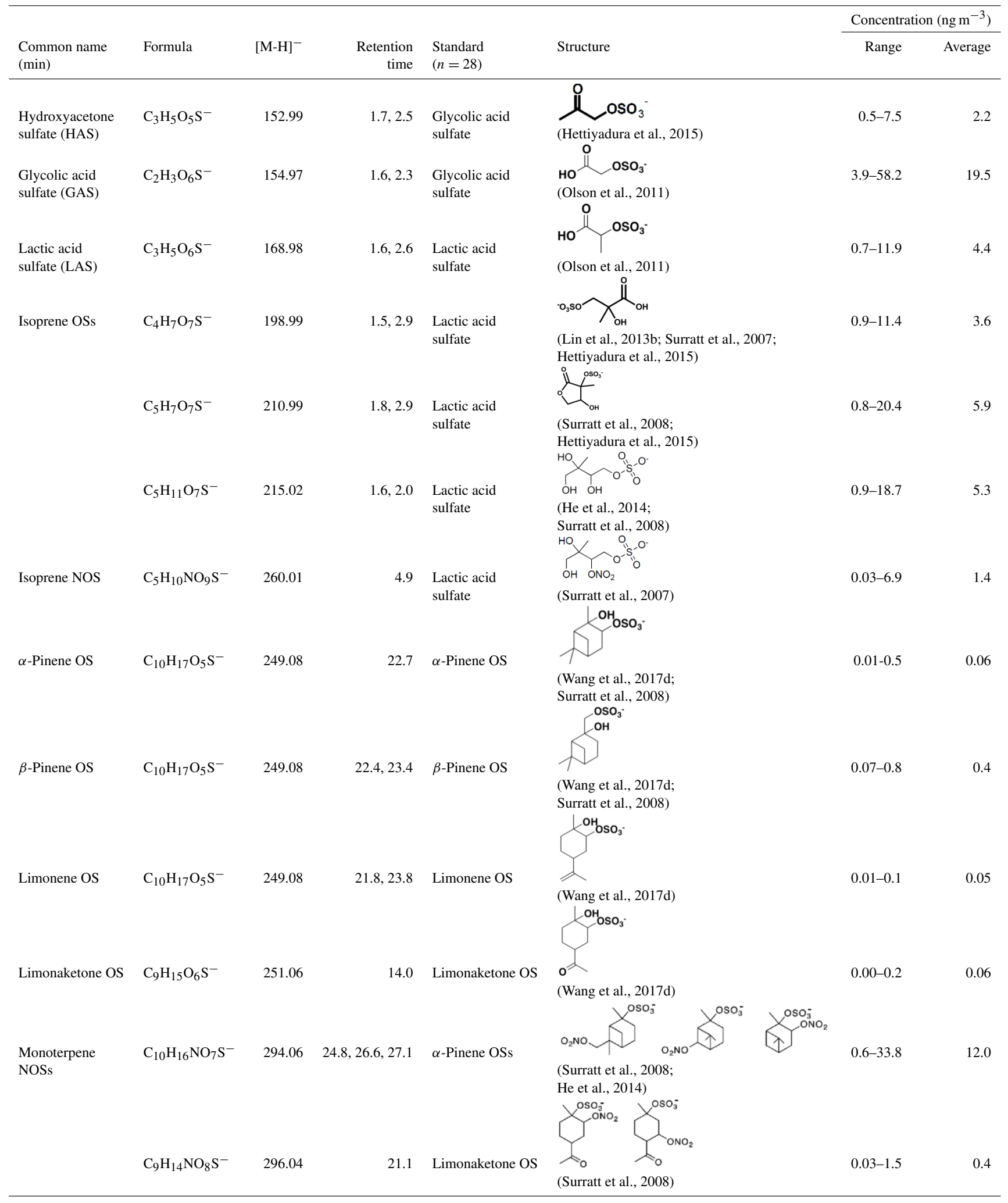



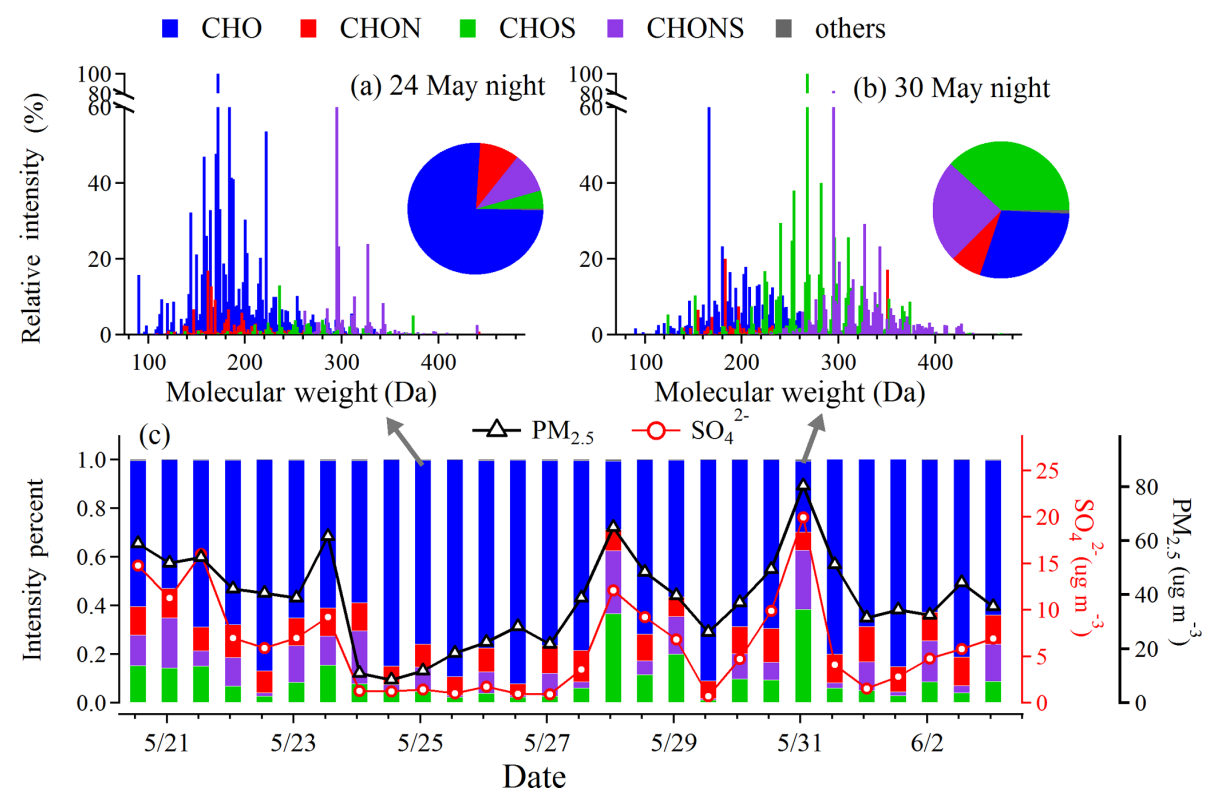

Figure 1. The intensity distribution of different compound categories (CHO, CHON, CHOS, and CHONS) (a) on a clean day and (b) on a polluted day. (c) Temporal variation in $\mathrm{PM}_{2.5}, \mathrm{SO}_{4}^{2-}$, and intensity percentages of different compound categories. The highly water-soluble OS species (e.g., isoprene OSs) with lower MW are absent in these figures and details are described in Sect. 3.1.

\section{Results and discussion}

\subsection{Overall molecular characterization of S-containing organics}

On average, $62 \%$ of the observed peaks in ESI negative mode are assigned with unambiguous molecular formulas. All the assigned formulas were classified into four major categories based on their elemental compositions, including $\mathrm{CHO}, \mathrm{CHON}, \mathrm{CHOS}$, and CHONS. As an example, CHONS refers to compounds that contain $\mathrm{C}, \mathrm{H}, \mathrm{O}, \mathrm{N}$, and $\mathrm{S}$ elements in the formula. Other compound categories are defined analogously. The percent of different compound categories in terms of number and intensity is shown in Fig. S4 and Fig. 1, in which "others" (e.g., CH, CHN, CHS, CHNS) refers to the compounds excluded from the above major compound categories. During pollution episodes, the number and intensity percent of S-containing compounds (CHOS and CHONS) increased obviously (Figs. 1, S4). The OC content in each sample for Orbitrap MS analysis was kept roughly constant to minimize variation arising from matrix ion suppression. Taking the nighttime sample of 24 May (0524N) as an example of clean days and the nighttime sample of 30 May $(0530 \mathrm{~N})$ as an example of polluted days, the mass spectra of different compound categories in each sample are shown and compared in Fig. 1a and b. The increase in S-containing organics indicated their important contribution to SOA when pollution accumulated. In addition, the S-containing compounds contributed more to the higher-MW formulas than CHO $\left(\mathrm{O}_{1}-\mathrm{O}_{10}\right)$ or CHON $\left(\mathrm{O}_{1}-\mathrm{O}_{11}\right)$ compounds (Fig. 1) due to the existence of more $\mathrm{O}\left(\mathrm{CHOS}: \mathrm{O}_{1}-\mathrm{O}_{12}, \mathrm{CHONS}\right.$ : $\mathrm{O}_{1-}$
$\left.\mathrm{O}_{14}\right)$ atoms and heteroatoms $(\mathrm{S}, \mathrm{N})$ in the molecules. The increasing trend of S-containing organics (Fig. S4) with larger MW than those of $\mathrm{CHO}$ or CHON may play important roles in the increase in SOA mass concentrations during pollution episodes.

The CHOS formulas with $\mathrm{O} / \mathrm{S} \geq 4$ allow for the possible assignment of a sulfate group in the molecules (i.e., OSs; Lin et al., 2012). Among all the identified CHOS formulas, $60 \%-99 \%$ (93\% on average) and 66-100\% (96\% on average) of them could be assigned as OSs in terms of number and intensity percent. Analogously, the CHONS formulas with $\mathrm{O} /(\mathrm{S}+\mathrm{N}) \geq 7$ could likely be NOS formulas, which account for $22-78 \%$ (53\% on average) by number and $18-94 \%$ (61\% on average) by intensity of all the identified CHONS formulas. As OSs and NOSs were assigned based on the molecular formulas alone, we could not completely exclude the possibility of CHOS being hydroxysulfonates and CHONS being nitro-OSs due to the lack of MS-MS analysis. According to a previous study, the presence of organosulfonate or nitro-OSs was usually limited compared to OSs or nitrooxy-OSs (Lin et al., 2012), and thus they were not taken into consideration in this study. A total of 351 OS and 181 NOS formulas were identified among all the samples during the campaign. The temporal variation in the total number and intensity of OSs and NOSs is shown in Fig. S4. During pollution episodes (nighttime of 27 May to nighttime of 28 May, nighttime of 29 May to nighttime of 30 May), the total number and intensity of OS formulas increased (Fig. S4). The total number of NOSs also showed a similar increasing trend during pollution episodes, while the total intensity of NOSs 
showed nighttime enhancement during the whole observation period (Fig. S4). Previous studies suggested that some NOS species could form via $\mathrm{NO}_{3}$-initiated oxidation under high- $\mathrm{NO}_{x}$ conditions at night (Surratt et al., 2008; Iinuma et al., 2007; Gomez-Gonzalez et al., 2008), which will be further discussed in the following sections.

Some of the more abundant OS and NOS peaks identified in the samples on the clean day $(05 / 24 \mathrm{~N})$ or during pollution episodes $(05 / 30 \mathrm{D}, 05 / 30 \mathrm{~N})$ are listed in Table S2. For example, deprotonated molecules $\mathrm{C}_{9} \mathrm{H}_{15} \mathrm{SO}_{7}^{-}, \mathrm{C}_{10} \mathrm{H}_{17} \mathrm{SO}_{7}^{-}$, and $\mathrm{C}_{9} \mathrm{H}_{17} \mathrm{SO}_{6}^{-}$were observed among the highest $\mathrm{OS}$ peaks in samples during pollution episodes (Table S2). These compounds could be derived from the oxidation of alkanes or diesel fuel based on previous chamber studies (Riva et al., 2016c; Blair et al., 2017). Many OSs previously designated as biogenic origins were also found in the anthropogenic sources (Blair et al., 2017), which may raise uncertainty when assigning OS sources in field observation studies. OS compounds derived from anthropogenic VOC precursors were widely observed in ambient aerosols (Table S2), but they were not quantified due to the lack of standards in this paper. They will be further investigated in our future studies. Other OS molecules (e.g., $\mathrm{C}_{9} \mathrm{H}_{15} \mathrm{SO}_{6}^{-}, \mathrm{C}_{10} \mathrm{H}_{17} \mathrm{SO}_{5}^{-}$) could be formed via the oxidation of monoterpenes (Surratt et al., 2008). For NOSs, ions $\mathrm{C}_{10} \mathrm{H}_{16} \mathrm{NO}_{7} \mathrm{~S}^{-}, \mathrm{C}_{10} \mathrm{H}_{16} \mathrm{NO}_{9} \mathrm{~S}^{-}$, and $\mathrm{C}_{10} \mathrm{H}_{16} \mathrm{NO}_{10} \mathrm{~S}^{-}$were among the highest peaks (Table $\mathrm{S} 2$ ). They could form via the nighttime $\mathrm{NO}_{3}$-initiated oxidation of monoterpenes (Surratt et al., 2008). These are just some examples with higher relative intensity (RI). The RI may not accurately represent their relative concentration levels in each sample, as the MS responses of different OSs are also influenced by different carbon chain structures (Wang et al., 2017d). The OS species of low MW and short carbon chain structures (with fewer than six carbon atoms in the molecule) are less retained on the SPE cartridges due to their highly water-soluble and more hydrophilic properties (Gomez-Gonzalez et al., 2008; Lin et al., 2012, 2010). As such, they were largely absent among the OS formulas detected by Orbitrap MS in this work. Hydroxyacetone sulfate $\left(\mathrm{C}_{3} \mathrm{H}_{5} \mathrm{O}_{5} \mathrm{~S}^{-}\right)$was detected by Orbitrap MS only in several samples with relatively higher concentrations. Hydroxycarboxylic acid sulfate $\left(\mathrm{C}_{2} \mathrm{H}_{3} \mathrm{O}_{6} \mathrm{~S}^{-}, \mathrm{C}_{3} \mathrm{H}_{5} \mathrm{O}_{6} \mathrm{~S}^{-}\right)$or isoprene OSs $\left(\mathrm{C}_{4} \mathrm{H}_{7} \mathrm{O}_{7} \mathrm{~S}^{-}, \mathrm{C}_{5} \mathrm{H}_{7} \mathrm{O}_{7} \mathrm{~S}^{-}, \mathrm{C}_{5} \mathrm{H}_{11} \mathrm{O}_{7} \mathrm{~S}^{-}\right)$are also sufficiently hydrophilic that few would be in the SPE eluate fraction, which was subjected to Orbitrap MS analysis. This explains why these highly water-soluble OS species with lower MW are absent in Fig. 1. Though these OS species were not detected by Orbitrap MS, some of them were quantified with high concentrations in ambient aerosols in the LC-MS analysis (Table 1), as the sample aliquots for the LC-MS analysis did not involve SPE treatment.

\subsection{Abundance of identified OSs and NOSs in ambient aerosols}

To further investigate the abundance and formation pathways of OSs and NOSs in ambient aerosols, some species were then quantified by HPLC-MS using authentic standards when available or surrogate standards. The quantified species could usually be formed via the interaction between biogenic precursors (e.g., isoprene, monoterpene) and anthropogenic pollutants (e.g., $\mathrm{SO}_{4}^{2-}, \mathrm{NO}_{x}$ ), which have been reported in previous chamber studies (Surratt et al., 2007, 2008, 2010). A total of 10 OSs and 3 NOS species were quantified in this study and their concentrations are listed in Table 1 . The molecules with the same molecular formula were treated as one species (e.g., monoterpene NOSs with [M-H] at $m / z 294$ were treated as one NOS species). The average concentration of all the quantified OSs was $41.4 \mathrm{ng} \mathrm{m}^{-3}$ during the campaign. The total OSs accounted for $0.31 \%$ of OM, with a maximum contribution of $0.65 \%$ on the night of 30 May. The total concentration of quantified NOSs was $13.8 \mathrm{ng} \mathrm{m}^{-3}$, corresponding to $0.11 \%$ of OM, with a maximum contribution of $0.35 \%$ on the night of 23 May.

The concentrations of each OS or NOS species across this and prior studies are summarized in Table S3. The relative contribution of each species to the total OSs or NOSs is shown in Fig. 2. GAS was the most abundant species among all the quantified species. The concentrations of GAS were 3.9-58.2 $\mathrm{ng} \mathrm{m}^{-3}$, with an average of $19.5 \mathrm{ng} \mathrm{m}^{-3}$. The concentrations were higher than those observed in Mexico (4.1-7.0 $\mathrm{ng} \mathrm{m}^{-3}$ ), California (3.3-5.4 $\mathrm{ng} \mathrm{m}^{-3}$ ), and Pakistan (11.3 $\mathrm{ng} \mathrm{m}^{-3}$; Olson et al., 2011; Table S3). The GAS concentration level at Beijing was comparable to that reported in summertime Alabama, US (8-26.2 $\mathrm{ng} \mathrm{m}^{-3}$; Table S3), a location characterized by high biogenic emissions and affected by anthropogenic pollutants (Hettiyadura et al., 2015, 2017; Rattanavaraha et al., 2016). The concentrations of LAS were $0.7-12.0 \mathrm{ng} \mathrm{m}^{-3}$, with an average of $4.4 \mathrm{ng} \mathrm{m}^{-3}$. The LAS concentrations were also higher than those observed in Mexico (1.2-1.8 $\left.\mathrm{ng} \mathrm{m}^{-3}\right)$, California $\left(0.6-0.8 \mathrm{ng} \mathrm{m}^{-3}\right)$, and Pakistan $\left(3.8 \mathrm{ng} \mathrm{m}^{-3}\right)$, but lower than those observed in Alabama, US (16.5 $\mathrm{ng} \mathrm{m}^{-3}$; Olson et al., 2011; Hettiyadura et al., 2015, 2017; Table S3). Carboxylic acids mainly form via aqueous-phase oxidation in cloud or particle water, including both biogenic and anthropogenic sources (Charbouillot et al., 2012; Chebbi and Carlier, 1996). The relatively higher level of hydroxycarboxylic acid sulfate could be attributed to the favorable interaction between sulfate aerosols and carboxylic acids or other precursors in summertime Beijing, while the precursors and mechanisms remain unclear. Oxalic acid is usually the most abundant dicarboxylic acid in the atmosphere (Guo et al., 2010; Narukawa et al., 2003). The average concentration of oxalic acid in fine particles was $0.22 \mu \mathrm{g} \mathrm{m}^{-3}$, which was at a relatively high concentration level when compared with those reported in previous studies (0.02-0.32 g m $^{-3}$; Agarwal et al., 2010; Bikkina et al., 2017; 


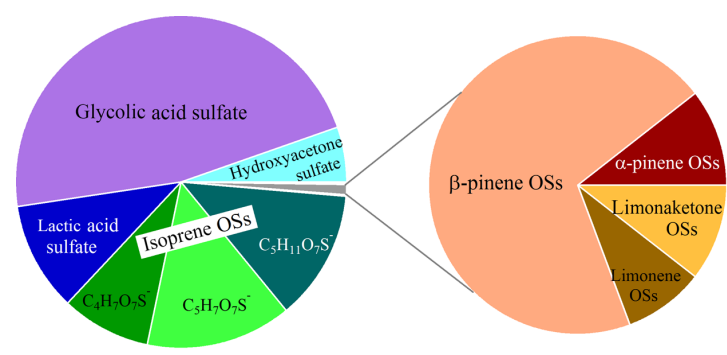

(a) OSs composition

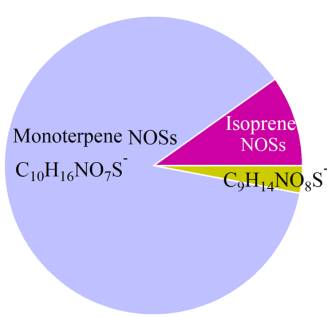

(b) NOSs composition

Figure 2. The relative contribution of different (a) OS and (b) NOS species. Only the selected species (semi-)quantified by HPLC-MS are included in this figure.

Boreddy et al., 2017; Deshmukh et al., 2017; Kawamura et al., 2010; Narukawa et al., 2003). Strong intercorrelations were found among GAS, LAS, and hydroxyacetone sulfate (HAS; Table S4), indicating their potentially similar precursors or formation pathways. They also showed strong correlations with isoprene oxidation products (MVK + MACR) and isoprene OSs (Table S4), suggesting isoprene-oxidized products as potential precursors of GAS, LAS, and HAS. It is suggested that both hydroxyacetone and carboxylic acids could be produced from the oxidation of isoprene (Fu et al., 2008; Carlton et al., 2009). GAS, LAS, and HAS have been reported to form via isoprene oxidation in the presence of acidic sulfate (Riva et al., 2016b; Surratt et al., 2008). GAS was also observed to form via the sulfate-induced oxidation of methyl vinyl ketone (MVK), an oxidation product of isoprene (Schindelka et al., 2013).

The concentration of quantified isoprene OSs $\left(\mathrm{C}_{4} \mathrm{H}_{7} \mathrm{O}_{7} \mathrm{~S}^{-}, \quad \mathrm{C}_{5} \mathrm{H}_{7} \mathrm{O}_{7} \mathrm{~S}^{-}, \quad\right.$ and $\left.\mathrm{C}_{5} \mathrm{H}_{11} \mathrm{O}_{7} \mathrm{~S}^{-}\right)$was $14.8 \mathrm{ng} \mathrm{m}^{-3}$, contributing to $36 \%$ of the total quantified OSs in this study. The isoprene OSs were lower than those observed in the southeastern US, with substantial isoprene emissions and impacted by anthropogenic pollutants, in which authentic standards were employed to quantify the isoprene OSs (Rattanavaraha et al., 2016). We used lactic acid sulfate as a surrogate standard to quantify isoprene OSs on the basis of their similar structures and retention times (Table 1). The isoprene concentration in the southeastern US (1.9 ppb; Xu et al., 2015) was much higher than that observed during our campaign (297 pptv). Besides the lower VOC precursors and measurement uncertainty, the lower isoprene OSs in this study could be attributed to different atmospheric conditions in Beijing from those in the southeastern US. IEPOX formation under low- $\mathrm{NO}_{x}$ conditions $\left(\mathrm{HO}_{2}\right.$ channel), usually with higher yields than oxidation products under high- $\mathrm{NO}_{x}$ conditions $\left(\mathrm{NO} / \mathrm{NO}_{2}\right.$; Worton et al., 2013), could be suppressed under the high- $\mathrm{NO}_{x}$ conditions (see Sect. 3.4 for the high- $\mathrm{NO}_{x}$ conditions) in Beijing (Zhang et al., 2017; Hu et al., 2015). The RH in Beijing was lower than that in the southeast US (Xu et al., 2015), which possibly led to an increase in aerosol viscosity and a decrease in diffusivity within the particles, resulting in lower OS formation (Shiraiwa et al., 2011). Moreover, the OM-coated particle structures observed in Beijing could reduce the reactive uptake of isoprene oxidation products (Li et al., 2016; Zhang et al., 2018; Riva et al., 2016a), which may be another possible reason for lower isoprene OSs in this study. The concentrations were comparable to those observed in suburban areas in the mid-Atlantic and Belgium and higher than those observed at the background site of the Pearl River Delta (PRD) region, China (Meade et al., 2016; Gómez-González et al., 2012; He et al., 2014), in which glycolic sulfate ester, ethanesulfonic acid, or camphor sulfonic acid were employed as surrogate standards. The isoprene OSs formed via the $\mathrm{HO}_{2}$ channel $\left(\mathrm{C}_{5} \mathrm{H}_{11} \mathrm{O}_{7} \mathrm{~S}^{-}\right)$were observed to be higher than those formed via the $\mathrm{NO} / \mathrm{NO}_{2}$ channel $\left(\mathrm{C}_{4} \mathrm{H}_{7} \mathrm{O}_{7} \mathrm{~S}^{-}\right.$; Table 1; Worton et al., 2013). Isoprene had a higher mixing ratio during the daytime (Fig. S5b), when $\mathrm{OH}$ radicals dominated the atmospheric oxidation capacity. Furthermore, the yield of isoprene oxidation via the $\mathrm{HO}_{2}$ channel is proposed to be higher than that via the $\mathrm{NO} / \mathrm{NO}_{2}$ channel (Worton et al., 2013). The concentration of $\mathrm{C}_{5} \mathrm{H}_{7} \mathrm{O}_{7} \mathrm{~S}^{-}$was comparable to that of $\mathrm{C}_{5} \mathrm{H}_{11} \mathrm{O}_{7} \mathrm{~S}^{-}$ (Table 1). $\mathrm{C}_{5} \mathrm{H}_{7} \mathrm{O}_{7} \mathrm{~S}^{-}$was suggested to be formed via isoprene oxidation and related to $\mathrm{C}_{5} \mathrm{H}_{11} \mathrm{O}_{7} \mathrm{~S}^{-}$(Surratt et al., 2008), while the formation mechanism remains unclear. The concentration of isoprene NOSs $\left(\mathrm{C}_{5} \mathrm{H}_{10} \mathrm{NO}_{9} \mathrm{~S}^{-}\right)$was lower than that of individual isoprene OSs. Strong intercorrelations were observed between isoprene OSs and NOSs (Table S4), suggesting their similar formation pathways via acid-catalyzed epoxide chemistry (Worton et al., 2013).

The average concentration of monoterpene OSs ( $\alpha$-pinene OSs, $\beta$-pinene OSs, limonene OSs, and limonaketone OSs) was $0.6 \mathrm{ng} \mathrm{m}^{-3}$, lower than those observed in the midAtlantic (Meade et al., 2016) and the Pearl River Delta in southern China where more abundant emissions of BVOC precursors are expected (Wang et al., 2017d; He et al., 2014; Table S3). The contribution of monoterpene OSs was much lower than that of isoprene OSs or other OSs (Fig. 2, Table 1$)$, as the mixing ratio of monoterpene ( $83 \mathrm{pptv})$ was lower than that of isoprene ( $297 \mathrm{pptv}$ ) during the campaign. 
Furthermore, the reactivity of monoterpenes with the $\mathrm{OH}$ radical is lower than that of isoprene (Carlton et al., 2009; Paulot et al., 2009; Atkinson et al., 2006). In contrast to isoprene OSs, the four monoterpene OS species did not show strong correlations with each other (Table S4), which may suggest their different oxidation mechanisms. While the contribution of monoterpene OSs was low, the monoterpene NOSs $\left(\mathrm{C}_{10} \mathrm{H}_{16} \mathrm{NO}_{7} \mathrm{~S}^{-}\right)$were the second most abundant signals among the observed species (Tables $1, \mathrm{~S} 2$ ), especially in the nighttime samples. The concentration of monoterpene NOSs $\left(\mathrm{C}_{10} \mathrm{H}_{16} \mathrm{NO}_{7} \mathrm{~S}^{-}\right)$was much higher than those observed in the mid-Atlantic and Belgium (Meade et al., 2016; Gómez-González et al., 2012), but lower than observed in the Pearl River Delta, China (He et al., 2014). $\mathrm{C}_{10} \mathrm{H}_{16} \mathrm{NO}_{7} \mathrm{~S}^{-}$ was also identified to be among the highest peaks in the mass spectra recorded by Orbitrap MS (Fig. 1b), with an RI of $83 \%$ in the sample of $05 / 30 \mathrm{~N}$ (Table S2). The monoterpene NOSs could be formed via nighttime $\mathrm{NO}_{3}$-initiated oxidation under high- $\mathrm{NO}_{x}$ conditions (Surratt et al., 2008; Iinuma et al., 2007; Gomez-Gonzalez et al., 2008). During the observation, both monoterpenes and $\mathrm{NO}_{x}$ showed higher mixing ratios at night (Fig. S5a, d), favorable for the $\mathrm{NO}_{3}$-initiated formation of NOSs.

\subsection{OS formation via acid-catalyzed aqueous-phase chemistry}

The time series of the total OS concentrations quantified by HPLC-MS are shown in Fig. 3, along with the meteorological conditions, $\mathrm{SO}_{2}$, aerosol LWC, acidity, $\mathrm{PM}_{2.5}$, and the major chemical components. Most OS species showed similar trends to the total OSs (Fig. S6), except for $\alpha$-pinene OSs and $\beta$-pinene OSs, which were observed at very low concentrations. During the campaign, particles were generally acidic with a $\mathrm{pH}$ range of 2.0-3.7, favorable for OS formation (Fig. 3). The aerosol acidity is indicated by aqueousphase $\left[\mathrm{H}^{+}\right]$in this study. The OS concentrations generally followed a similar trend to that of sulfate aerosols (Fig. 3). The total OS concentrations showed strong correlations with sulfate $(r=0.67)$ and aerosol acidity $(r=0.67)$, suggesting the driving role of acidic sulfate aerosols in OS formation (Table S4).

During the observation period, three pollution episodes (episodes I, II, III) were identified based on the $\mathrm{PM}_{2.5}$ concentrations, which are marked by gray shading in Fig. 3. The back trajectories, average concentrations of VOC precursors, and oxidants during each episode are also shown in Table S5. The most significant increasing trend of OSs was observed during pollution episode III (nighttime of 29 May to nighttime of 30 May). During this episode, the accumulation of secondary inorganic aerosols (SIAs), referring to sulfate, nitrate, and ammonium in this study, was dominated by sulfate. SIAs, especially sulfate and nitrate salts, represent the most important components driving the particle hygroscopicity (Wu et al., 2018; Xue et al., 2014), and thus the aerosol LWC increased with SIAs (Fig. 3). An increase in aerosol acidity was also observed during this episode (Fig. 3). OSs increased to the highest level $\left(129.2 \mathrm{ng} \mathrm{m}^{-3}\right)$ during the campaign under the condition of high sulfate aerosols, high aerosol acidity, and LWC (Fig. 3), suggesting the acidcatalyzed aqueous-phase formation of OSs in the presence of acidic sulfate aerosols. The higher aerosol LWC encountered during these periods would also favor the uptake of gasphase reactants into the particle phase due to the decrease in viscosity and increase in diffusivity within the particles (Shiraiwa et al., 2011). Moreover, the oxidant levels, indicated by $\mathrm{O}_{x}\left(\mathrm{NO}_{2}+\mathrm{O}_{3}\right)$ in this study (Herndon et al., 2008), were much higher than the other two episodes, which favored the formation of VOC oxidation products (e.g., MVK + MACR; Table S5). This is another reason for the higher OS concentration level during episode III. During pollution episode II (nighttime of 27 May to 28 nighttime of May), the OS concentration level was lower than during episode III. It is noted that the increases in sulfate, aerosol LWC, and acidity were also less than during episode III, indicating less aqueousphase formation of OSs. During this episode, the increase in SIAs was attributed to both sulfate and nitrate, the two with comparable contributions to the total SIAs. In contrast to episodes II and III, the SIA accumulation was dominated by nitrate during episode I (21-23 May). OS and sulfate aerosols stayed at a medium concentration level, lower than during the other two episodes. During the daytime of 21 May, aerosol acidity increased due to the elevated relative contribution of sulfate compared to that of nitrate, and thus the OS concentration also increased. During the daytime of 23 May, higher aerosol LWC was observed due to the rapid increase in nitrate; however, the aerosol acidity was lower as a result of the lower contribution from sulfate. Thus, the increase in OS concentration was not very obvious. OS formation may be limited by aerosol acidity, indicating the importance of acid-catalyzed chemistry. Stronger correlations between OSs and sulfate $(r=0.67)$ or aerosol acidity $(r=0.67)$ compared with that between OSs and LWC $(r=0.55)$ also suggest the importance of acid-catalyzed chemistry for OS formation. The back trajectories during episode I were different from those during episode II or III (Table S5), which could be one reason for different conditions (e.g., SIA composition) during episode I. This episode ended with the rain elimination event on the afternoon of 23 May. The OSs were at low concentrations from 24 May to the daytime of 27 May, when sulfate, $\mathrm{SO}_{2}$, aerosol acidity, and LWC were noticeably lower than the other periods, restraining OS formation.

The three pollution episodes were characterized by different inorganic aerosol compositions and aerosol properties (e.g., acidity, LWC), resulting in different levels of OS formation. The concentrations and relative contributions of sulfate, aerosol acidity, and LWC are important factors influencing OS formation. OS concentrations generally increased with the increasing of sulfate, aerosol acidity, and LWC (Fig. 3), suggesting more active OS formation via acid- 


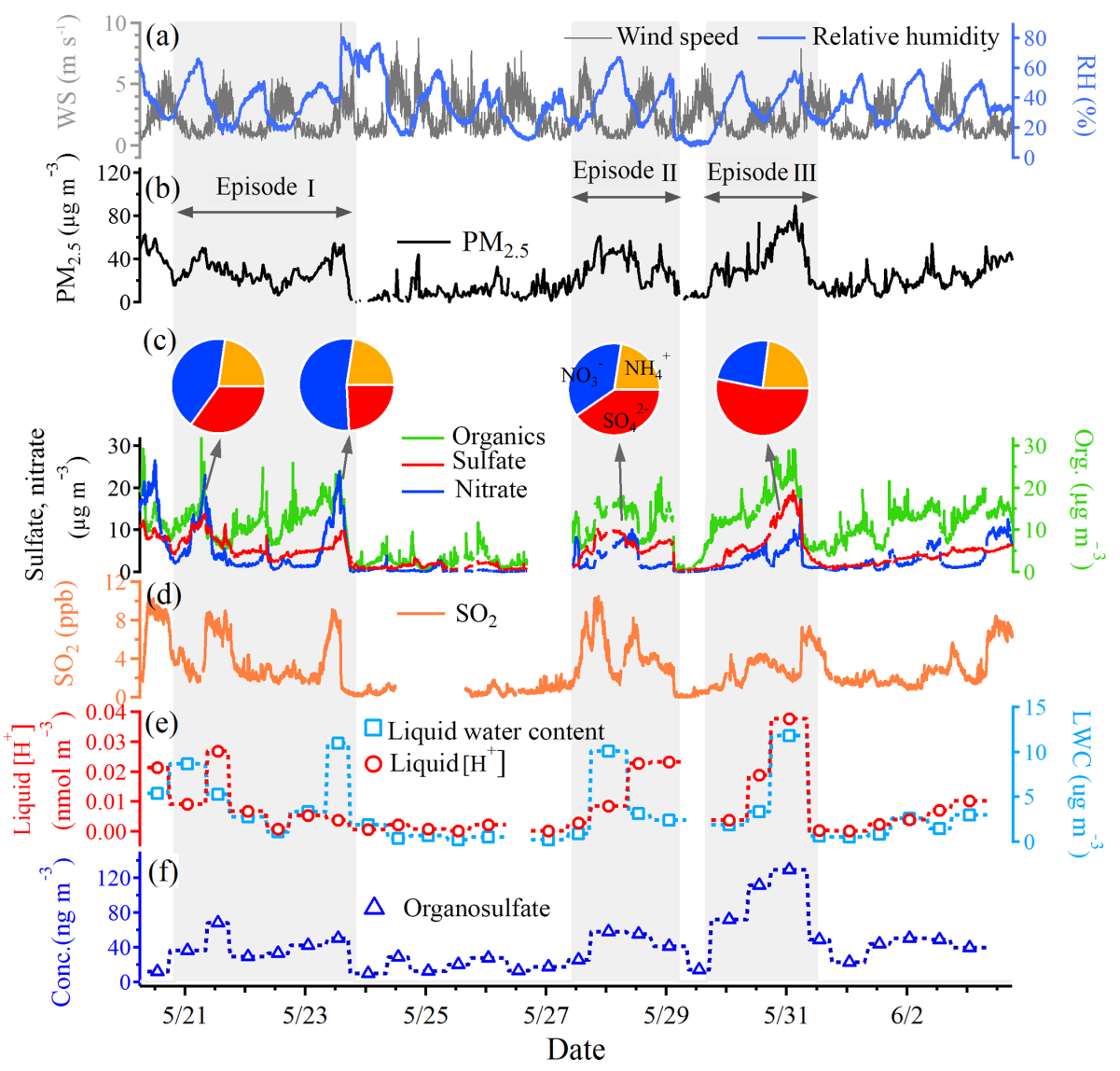

Figure 3. Time series of (a) wind speed (WS) and relative humidity (RH), (b) $\mathrm{PM}_{2.5}$, (c) mass concentrations of organics, sulfate, nitrate, and composition of secondary inorganic aerosols during pollution episodes, (d) $\mathrm{SO}_{2}$, (e) liquid water content (LWC) and aqueous-phase $\left[\mathrm{H}^{+}\right]$, and (f) the total concentrations of OSs quantified by HPLC-MS. The pollution episodes are marked by gray shading.

catalyzed aqueous-phase reactions in the presence of sulfate. These influencing factors were interrelated. Both sulfate and nitrate are important hygroscopic components (Chan and Chan, 2005; Wu et al., 2018; Xue et al., 2014) favoring the water uptake of aerosols and thus increasing LWC. The increasing of aerosol LWC with SIAs was observed (Fig. 3). A previous study also suggested that at a given $\mathrm{RH}$, aerosol LWC was nearly linearly related to the sum of nitrate and sulfate mass concentrations (Guo et al., 2016). The variation in SIA composition and LWC would then influence the aerosol acidity (Liu et al., 2017; Guo et al., 2016). In this study, higher aerosol acidity was observed with an elevated contribution of sulfate among SIAs (Fig. 3). This is in accord with a previous study suggesting that particle $\mathrm{pH}$ was generally below 2 when aerosol anionic composition was dominated by sulfate $\left(\mathrm{NO}_{3}^{-} / 2 \mathrm{SO}_{4}^{2-}\right.$ mole ratio $>1$; Guo et al., 2016).

To further elucidate the major factors influencing OS formation and their interrelations with SIA compositions, the distribution of OS concentrations as a function of $\mathrm{SO}_{4}^{2-}$ / SIA mass concentration ratios and other related factors is plotted in Fig. 4. The aerosol LWC generally increased with the increasing of the SIA mass concentrations, while the aerosol acidity was also influenced by the relative contribution of $\mathrm{SO}_{4}^{2-}$ and $\mathrm{NO}_{3}^{-}$to SIAs. When the SIAs were dominated by $\mathrm{SO}_{4}^{2-}\left(\mathrm{SO}_{4}^{2-} / \mathrm{SIA}>0.5\right)$, the aerosol acidity increased obviously as a function of $\mathrm{SO}_{4}^{2-}$ / SIA mass concentration ratios and $\mathrm{pH}$ values were generally below 2.8 (Fig. 4b, d). The high aerosol acidity was favorable for OS formation and OS concentration also increased as a function of sulfate mass concentration and fraction (Fig. 4a). The pollution episode III (Fig. 3) was the typical case for this condition. When the SIAs were dominated by nitrate $\left(\mathrm{SO}_{4}^{2-} / \mathrm{SIA}<0.5\right)$, high LWC may occur due to high concentrations of hygroscopic SIAs, while the aerosol acidity was relatively lower due to the lower sulfate fraction than that of nitrate (Fig. 4). The increasing trend of OSs as a function of sulfate or $\mathrm{SO}_{4}^{2-}$ / SIA mass concentration ratios was not as obvious as the sulfate-dominant condition $\left(\mathrm{SO}_{4}^{2-} / \mathrm{SIA}>0.5\right)$ because OS formation may be limited by lower aerosol acidity. The daytime of 23 May during pollution episode I (Fig. 3) was the typical case for this atmospheric condition. Overall, OS formation would obviously be promoted via acid-catalyzed aqueous-phase re- 

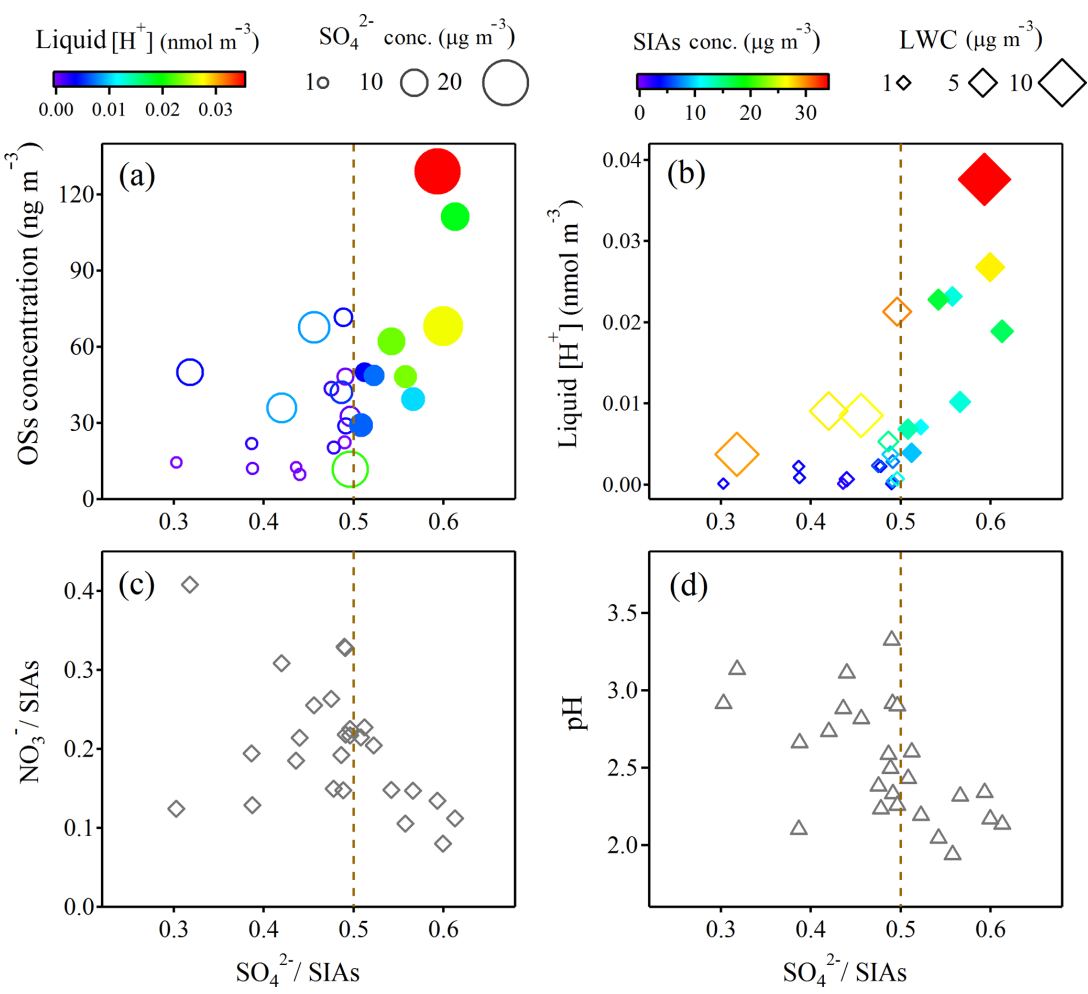

Figure 4. (a) The OS concentrations as a function of the $\mathrm{SO}_{4}^{2-} / \mathrm{SIA}$ mass ratios. The circles are colored according to the liquid [H $\left.\mathrm{H}^{+}\right]$ concentration and the sizes of the circles are scaled to the $\mathrm{SO}_{4}^{2-}$ mass concentration. (b) The liquid $\left[\mathrm{H}^{+}\right]$as a function of the $\mathrm{SO}_{4}^{2-} / \mathrm{SIA}^{-2}$ mass ratios. The markers are colored according to the SIA mass concentrations and the sizes of the markers are scaled to the liquid water content (LWC). (c) The $\mathrm{NO}_{3}^{-} / \mathrm{SIA}$ mass ratios as a function of the $\mathrm{SO}_{4}^{2-} / \mathrm{SIA}$ mass ratios. (d) The aerosol $\mathrm{pH}$ as a function of the $\mathrm{SO}_{4}^{2-} / \mathrm{SIA}$ mass ratios. The solid markers represent those among the range $\mathrm{SO}_{4}^{2-} / \mathrm{SIA}>0.5$ and open markers represent those among the range $\mathrm{SO}_{4}^{2-} / \mathrm{SIA}<0.5$ in (a) and (b). When sulfate dominated the accumulation of secondary inorganic aerosols $\left(\mathrm{SO}_{4}^{2-} / \mathrm{SIA}^{2} 0.5\right)$, both aerosol LWC and acidity $(\mathrm{pH}<2.8)$ increased and OS formation was obviously promoted. In comparison, acid-catalyzed OS formation was limited by lower aerosol acidity under nitrate-dominant conditions.

actions when SIA accumulation is dominated by sulfate $\left(\mathrm{SO}_{4}^{2-} / \mathrm{SIA}>0.5\right)$.

\subsection{Monoterpene $\mathrm{NOS}$ formation via nighttime $\mathrm{NO}_{3}$ oxidation}

A recent study suggested that nearly all BVOCs could be oxidized overnight and are dominated by reactions via $\mathrm{NO}_{3}$ oxidation at $\mathrm{NO}_{x} /$ BVOCs ratios higher than 1.4 (Edwards et al., 2017). When we roughly estimated the BVOC concentration to be the sum of isoprene, MVK + MACR, and monoterpenes, the $\mathrm{NO}_{x} / \mathrm{BVOCs}$ ratios were higher than 10 at night (Fig. S5). This indicated the dominant nighttime BVOC loss via $\mathrm{NO}_{3}$-initiated oxidation in summer in Beijing. The oxidation of BVOCs was found to be controlled by $\mathrm{NO}_{3}$ oxidation rather than $\mathrm{O}_{3}$ oxidation during the campaign, which contributed to a total of $90 \%$ of BVOC reactivity at night (Wang et al., 2018). Nighttime enhancement of monoterpene NOSs was clearly observed under high- $\mathrm{NO}_{x}$ conditions (Fig. 5). The nighttime concentrations of $\mathrm{C}_{10} \mathrm{H}_{16} \mathrm{NO}_{7} \mathrm{~S}^{-}$and $\mathrm{C}_{9} \mathrm{H}_{14} \mathrm{NO}_{8} \mathrm{~S}^{-}$were respectively $1.3-31.4$ (9.8 on average) and 0.9-19.7 (5.8 on average) times larger than daytime concentrations. Higher mixing ratios of monoterpenes were observed at night (Fig. S5), when high $\mathrm{NO}_{x}$ concentrations (Fig. 5) favored the formation of monoterpene NOSs via the $\mathrm{NO}_{3}$-initiated oxidation of monoterpenes. The elevated nighttime concentrations of monoterpene NOSs was also observed in previous studies (Surratt et al., 2008; Iinuma et al., 2007; Gomez-Gonzalez et al., 2008). High correlations between $\mathrm{N}_{2} \mathrm{O}_{5}$ and $\mathrm{NO}_{2}$ or $\mathrm{NO}_{3}$ radical production were observed (Wang et al., 2018), so the $\mathrm{NO}_{2}$ concentration was employed to investigate $\mathrm{NO}_{3}$ oxidation during the campaign in this study. Higher concentrations of monoterpene NOSs $\left(\mathrm{C}_{10} \mathrm{H}_{16} \mathrm{NO}_{7} \mathrm{~S}^{-}\right)$were found with elevated $\mathrm{NO}_{2}$ levels at night (Fig. 6), indicating the plausibility of more NOS formation via $\mathrm{NO}_{3}$-initiated oxidation. When $\mathrm{NO}_{2}$ increased to higher than $20 \mathrm{ppb}$, the NOS concentration did not further increase obviously with $\mathrm{NO}_{2}$, which suggested that $\mathrm{NO}_{2}$ was in excess and no longer the limiting factor in NOS formation. The highest nighttime concentration of $\mathrm{C}_{10} \mathrm{H}_{16} \mathrm{NO}_{7} \mathrm{~S}^{-}$ was recorded on 27 May during episode II (Fig. 5). Besides 


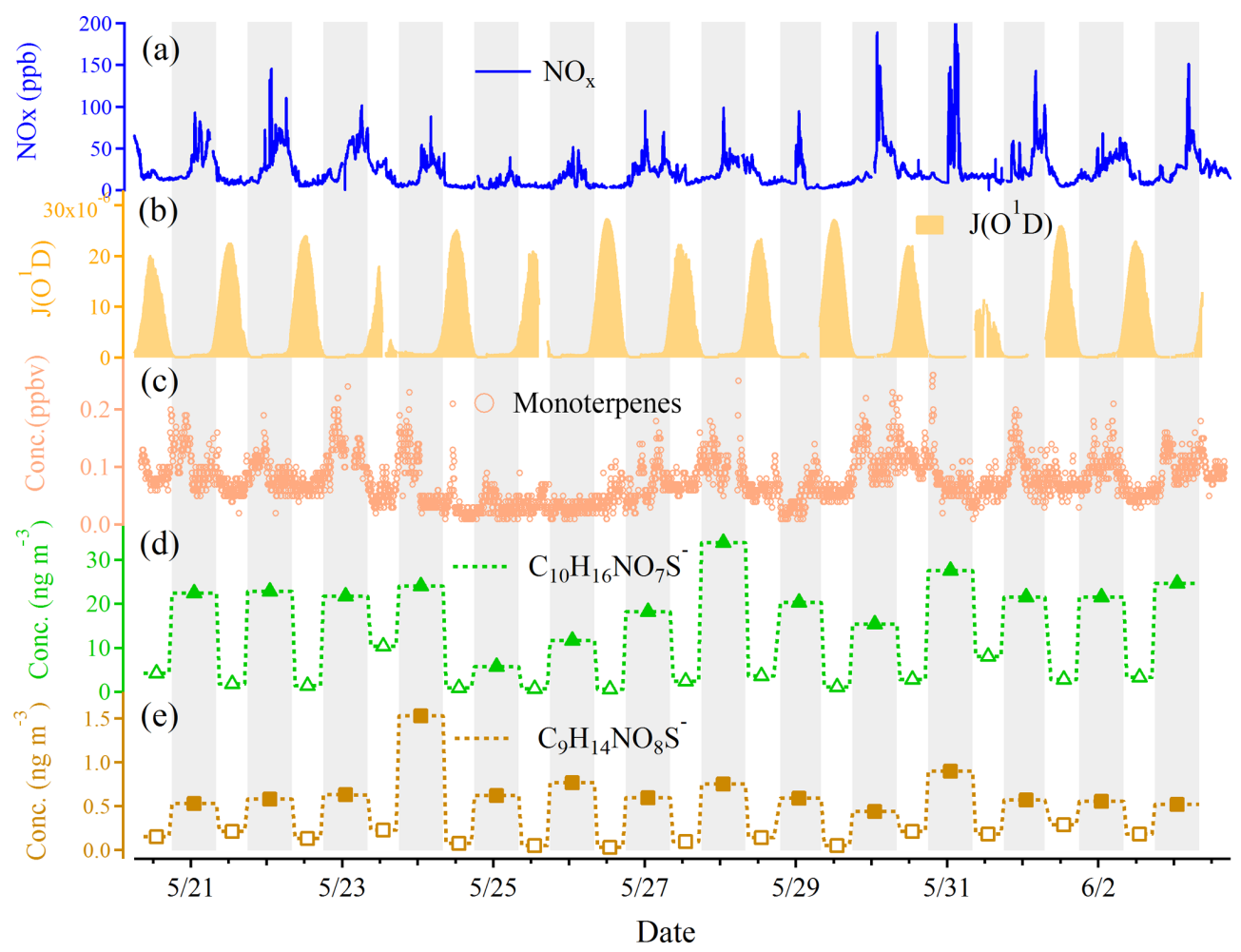

Figure 5. Time series of (a) $\mathrm{NO}_{x}$, (b) $\mathrm{J}\left(\mathrm{O}^{1} \mathrm{D}\right)$, (c) monoterpene, (d) monoterpene NOSs $\left(\mathrm{C}_{10} \mathrm{H}_{16} \mathrm{NO}_{7} \mathrm{~S}^{-}\right)$, and (e) limonaketone $\mathrm{NOSs}$ $\left(\mathrm{C}_{9} \mathrm{H}_{14} \mathrm{NO}_{8} \mathrm{~S}^{-}\right)$. The gray background denotes the nighttime and the white background denotes the daytime.

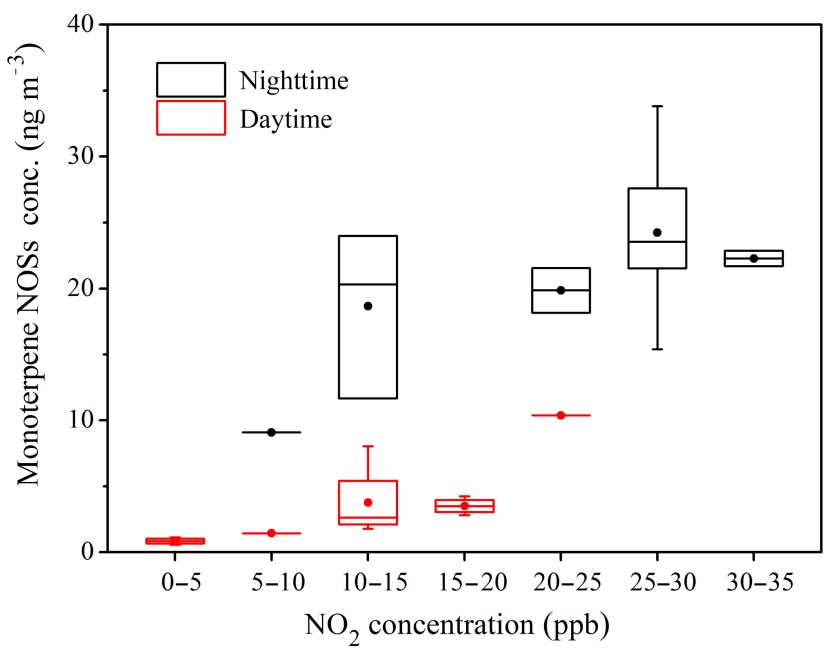

Figure 6. The concentrations of monoterpene NOSs $\left(\mathrm{C}_{10} \mathrm{H}_{16} \mathrm{NO}_{7} \mathrm{~S}^{-}\right)$as a function of $\mathrm{NO}_{2}$ concentration bins (ppb) during daytime and nighttime. The closed circles represent the mean values and whiskers represent 25 and 75 percentiles.

the high $\mathrm{NO}_{2}$ concentration ( $>20 \mathrm{ppb}$ ), the high monoterpene level was another primary reason for the elevated concentration of monoterpene NOSs (Table S5).

The lower concentrations of monoterpene NOSs during the daytime could be attributed to the lower monoterpene,
$\mathrm{NO}_{x}$, and $\mathrm{NO}_{x} / \mathrm{BVOCs}$ ratios than at night (Fig. S5). Monoterpene NOSs, also as organic nitrate $\left(\mathrm{R}-\mathrm{ONO}_{2}\right) \mathrm{com}$ pounds, may go through decomposition via photolysis or $\mathrm{OH}$ oxidation during the daytime (He et al., 2011; Suarez-Bertoa et al., 2012). Organic nitrates have been estimated to have a short lifetime of several hours (Lee et al., 2016). Elevation in the concentrations of monoterpene NOSs were also observed with the increasing of $\mathrm{NO}_{2}$ during daytime, but the concentrations were much lower and the increase was less prominent than during the nighttime (Fig. 6). The highest daytime concentration of $\mathrm{C}_{10} \mathrm{H}_{16} \mathrm{NO}_{7} \mathrm{~S}^{-}$was recorded on 23 May (10.6 $\mathrm{n} \mathrm{m}^{-3}$ ), followed by the daytime of 31 May $\left(8.0 \mathrm{ng} \mathrm{m}^{-3}\right)$. The $\mathrm{NO}_{2}$ concentrations were in the range of 20-25 and 10-15 ppb during the daytime of 23 and 31 May, respectively. It is noted that the $\mathrm{J}\left(\mathrm{O}^{1} \mathrm{D}\right)$ values during the daytime of 23 and 31 May were much lower than other daytime periods (Fig. 5), indicating the possibility of less decomposition of monoterpene NOSs. Previous studies also reported that organic nitrates have much shorter lifetimes than the corresponding OSs, and thus it is possible that organic nitrates derived from monoterpene would undergo nucleophilic attack by sulfate and form monoterpene OSs or NOSs (He et al., 2014; Darer et al., 2011; Hu et al., 2011). Monoterpene NOSs could also undergo hydrolysis and form monoterpene OSs (Darer et al., 2011; Hu et al., 2011). These may be other potential pathways for the loss of monoterpene NOSs and 


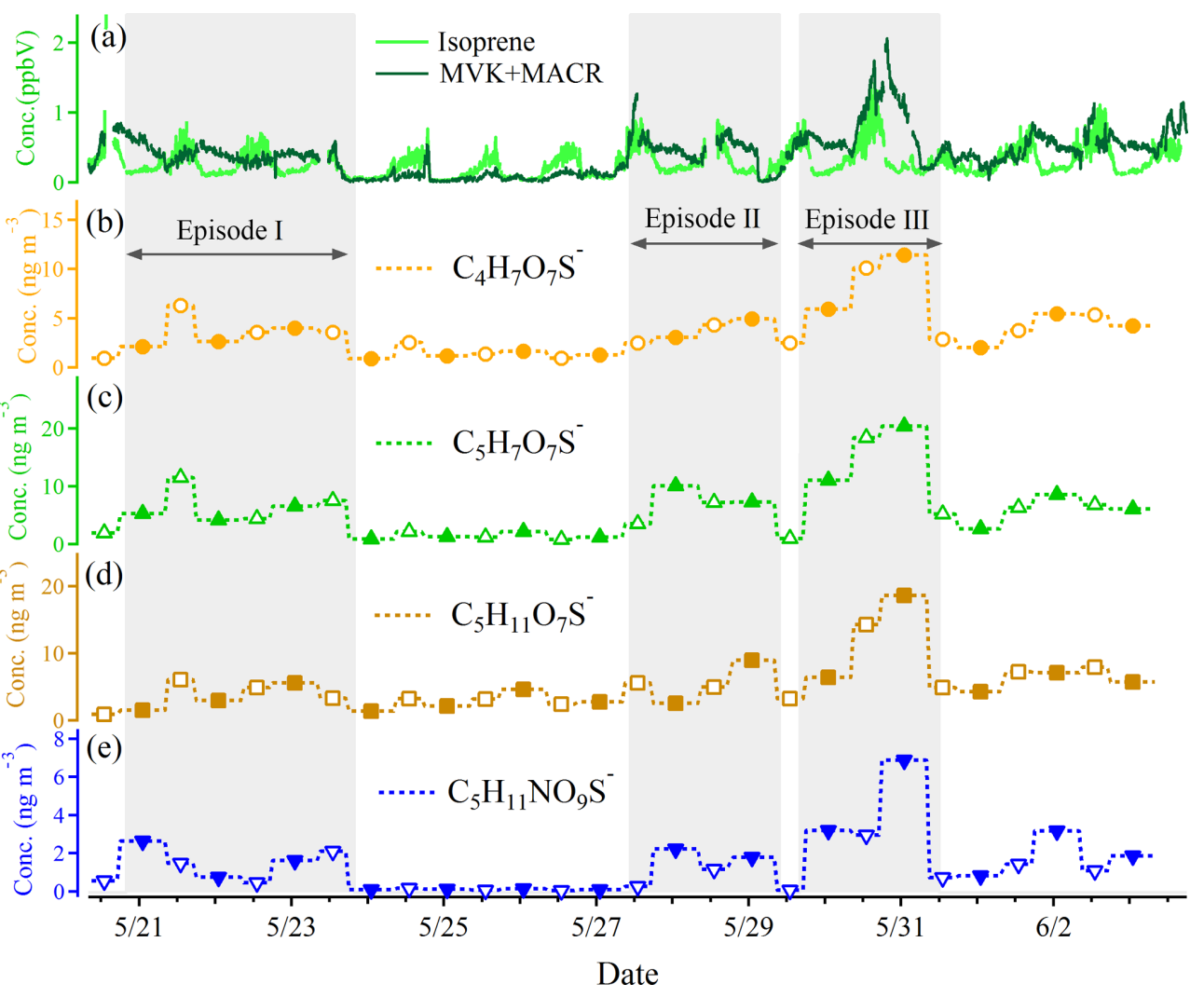

Figure 7. Time series of (a) isoprene and MVK+MACR, the isoprene OSs (b) $\mathrm{C}_{4} \mathrm{H}_{7} \mathrm{O}_{7} \mathrm{~S}^{-}$, (c) $\mathrm{C}_{5} \mathrm{H}_{7} \mathrm{O}_{7} \mathrm{~S}^{-}$, and (d) $\mathrm{C}_{5} \mathrm{H}_{11} \mathrm{O}_{7} \mathrm{~S}^{-}$, and the (e) NOSs $\left(\mathrm{C}_{5} \mathrm{H}_{11} \mathrm{NO}_{9} \mathrm{~S}^{-}\right)$. The pollution episodes are marked by gray shading. MVK and MACR are the abbreviations for methyl vinyl ketone and methacrolein, respectively.

the production of monoterpene OSs. These potential formation pathways of monoterpene OSs were different from the formation pathways via acid-catalyzed aqueous-phase reactions. This could be another explanation for the different temporal variations of some monoterpene OSs (Fig. S6) compared to other OSs.

\subsection{Formation pathways of isoprene OSs and NOSs}

In contrast to the day-night variation trend of monoterpene NOSs, isoprene NOSs $\left(\mathrm{C}_{5} \mathrm{H}_{11} \mathrm{NO}_{9} \mathrm{~S}^{-}\right)$displayed a similar temporal variation to isoprene OSs and the total OSs (Fig. 7). The formation of isoprene NOSs is presumed to have similar limiting factors to those affecting isoprene OSs, rather than those limiting the nighttime $\mathrm{NO}_{3}$-initiated formation of monoterpene NOSs. The strong correlation between isoprene OSs and NOSs also indicated their similar formation pathways or limiting factors in formation (Table S4). The oxidation of isoprene could form isoprene epoxydiols (IEPOXs), hydroxymethyl-methyl-lactone (HMML), or methacrolein (MACR) and methacrylic acid epoxide (MAE; Paulot et al., 2009; Lin et al., 2013b; Worton et al., 2013; Nguyen et al., 2015). Both isoprene OSs and NOSs showed strong correlations with isoprene oxidation products (MVK + MACR; Ta- ble S4). The isoprene OSs could be formed through ringopening epoxide reactions of isoprene oxidation products, which was shown to be a kinetically feasible pathway (Minerath and Elrod, 2009; Worton et al., 2013). Isoprene OSs were also proposed to form by the reactive uptake and oxidation of MVK or MACR (oxidation products of isoprene) initiated by the sulfate radicals (Nozière et al., 2010; Schindelka et al., 2013). Isoprene NOSs generally increased with the increasing of isoprene oxidation products (MVK + MACR) and acidic sulfate aerosols (Figs. 3 and 7, Table S4). It indicates that isoprene NOSs form via acid-catalyzed reactions or the reactive uptake of oxidation products of isoprene by sulfate, rather than $\mathrm{NO}_{3}$-initiated oxidation pathways. The highest concentrations of isoprene OSs and NOSs were observed during the nighttime of 30 May during episode III (Fig. 7), with high sulfate, MVK + MACR, aerosol acidity, and LWC (Fig. 3, Table S5). In the formation of isoprene OSs or NOSs, epoxides first form carbocation intermediates through acidcatalyzed hydrolysis reactions, and then sulfate ions serve as nucleophiles in the subsequent fast step, forming OSs or NOSs (Minerath and Elrod, 2009). The presence of high levels of sulfate may effectively facilitate the ring-opening reaction of epoxide or the reactive uptake of oxidation products and subsequent OS or NOS formation (Surratt et al., 2010). 

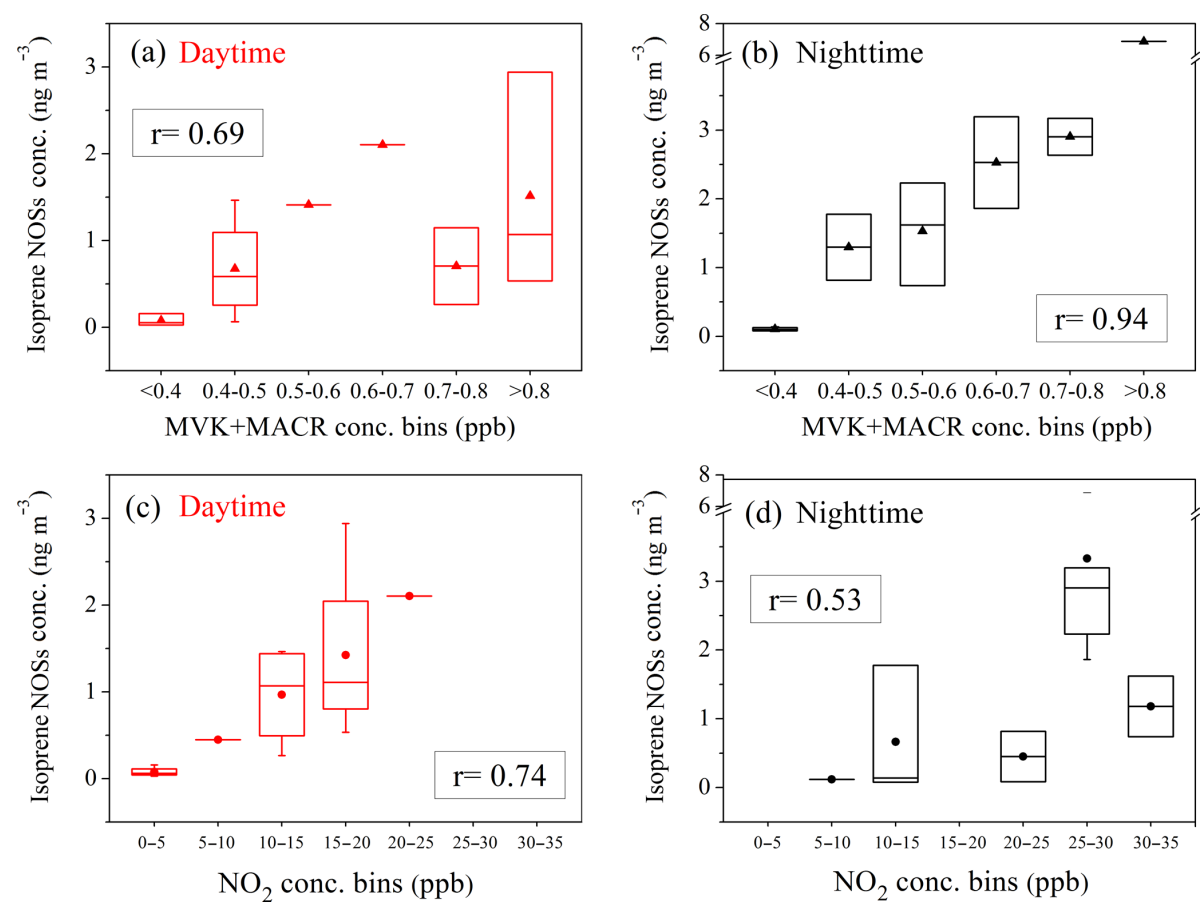

Figure 8. The isoprene $\mathrm{NOS}\left(\mathrm{C}_{5} \mathrm{H}_{11} \mathrm{NO}_{9} \mathrm{~S}^{-}\right)$concentrations as a function of $\mathrm{NO}_{2}$ or $\mathrm{MVK}+\mathrm{MACR}$ concentration bins (ppb) and the correlations between isoprene NOSs $\left(\mathrm{C}_{5} \mathrm{H}_{11} \mathrm{NO}_{9} \mathrm{~S}^{-}\right)$and $\mathrm{NO}_{2}$ or MVK + MACR. The closed markers in the box represent the mean values and whiskers represent 25 and 75 percentiles in each concentration bin. The $r$ value in each panel represents the correlation coefficient between isoprene NOSs and $\mathrm{NO}_{2}$ or MVK + MACR concentrations.

The proposed formation mechanisms of isoprene NOSs need to be further investigated and validated through laboratory studies.

Although the isoprene NOS formation was not via the $\mathrm{NO}_{3}$-initiated oxidation pathways, the $\mathrm{NO}_{3}$ radical could be involved in the formation pathways and influence the yield of isoprene NOSs. Considering the different atmospheric conditions during the daytime and nighttime, we analyzed the variation in daytime and nighttime isoprene NOSs separately (Fig. 8). Generally, higher concentrations of isoprene NOSs were found with elevated $\mathrm{NO}_{2}$ or MVK + MACR concentration levels. During daytime, the correlation of isoprene NOSs with $\mathrm{NO}_{2}(r=0.74)$ was stronger than that with MVK + MACR ( $r=0.69$; Fig. 8). When MVK + MACR was higher than $0.7 \mathrm{ppb}$, the NOS concentrations did not increase further with MVK + MACR. It was likely that the biogenic VOC precursors were in surplus under this condition and the formation of isoprene NOSs may be limited by the lower daytime $\mathrm{NO}_{2}$ concentration, sulfate aerosols, or other factors. During daytime, the MVK + MACR concentrations were generally higher and $\mathrm{NO}_{x}$ was lower (Fig. S5), and thus the $\mathrm{NO}_{2}$ level may limit the daytime formation of isoprene NOSs. During nighttime, a strong correlation between isoprene NOS and MVK + MACR $(r=0.94)$ was observed, while the increasing trend of isoprene NOSs as a function of $\mathrm{NO}_{2}(r=0.53)$ was not so obvious and their correlation was lower (Fig. 8). During nighttime, the $\mathrm{NO}_{x}$ concentra- tions were generally higher and MVK + MACR concentrations were lower (Fig. S5), and thus the concentrations of isoprene oxidation products (e.g., MVK + MACR) may be the limiting factor for the nighttime formation of isoprene NOSs. The threshold (e.g., $\mathrm{NO}_{x}$ / isoprene ratio, $\mathrm{NO}_{x}$ / isoprene oxidation product ratio) that makes the transition from $\mathrm{NO}_{x}$ limited to isoprene-limited (or isoprene oxidation products) still needs further investigation through laboratory studies.

\section{Conclusions}

An intensive field campaign was conducted to investigate the characterization and formation of OSs and NOSs in summer in Beijing under the influence of abundant biogenic emissions and anthropogenic pollutants (e.g., $\mathrm{NO}_{x}$, $\mathrm{SO}_{2}$, and $\mathrm{SO}_{4}^{2-}$ ). The overall molecular characterization of S-containing organics (CHOS, CHONS) was made through ESI Orbitrap MS data. More than $90 \%$ of the CHOS formulas could be assigned as OSs and more than half of the CHONS formulas could be assigned as NOSs based on the molecular formulas. The number and intensity of OSs and NOSs increased significantly during pollution episodes, which indicated they might play important roles for SOA accumulation.

To further investigate the distribution and formation pathways of OSs and NOSs in complex ambient atmosphere, 
some species were quantified using HPLC-MS, including 10 OSs and 3 NOS species. The total concentrations of quantified OSs and NOSs were 41.4 and $13.8 \mathrm{ng} \mathrm{m}^{-3}$, respectively, accounting for $0.31 \%$ and $0.11 \%$ of organic matter. Glycolic acid sulfate was the most abundant species $\left(19.5 \mathrm{ng} \mathrm{m}^{-3}\right)$ among all the quantified OS species. The strong correlations between GAS, LAS, HAS, and isoprene OSs indicated their potential formation pathways via isoprene oxidation in the presence of acidic sulfate aerosols. The concentration of isoprene OSs was $14.8 \mathrm{ng} \mathrm{m}^{-3}$ and the isoprene OSs formed via the $\mathrm{HO}_{2}$ channel were higher than that via the $\mathrm{NO} / \mathrm{NO}_{2}$ channel. The contribution of monoterpene OSs was much smaller than other OSs, while monoterpene NOSs $\left(\mathrm{C}_{10} \mathrm{H}_{16} \mathrm{NO}_{7} \mathrm{~S}^{-}\right)$were observed at high concentrations $\left(12.0 \mathrm{ng} \mathrm{m}^{-3}\right)$, especially in nighttime samples.

OS concentrations generally increased with the increase in acidic sulfate aerosols, aerosol acidity, and LWC, indicating the acid-catalyzed aqueous-phase formation of OSs in the presence of acidic sulfate aerosols as an effective formation pathway. The sulfate concentration, SIA composition, aerosol acidity, and LWC are important factors influencing OS formation. When sulfate dominated the SIA accumulation $\left(\mathrm{SO}_{4}^{2-} / \mathrm{SIA}>0.5\right)$, the aerosol acidity would increase obviously as a function of $\mathrm{SO}_{4}^{2-}$ / SIA mass concentration ratios and the $\mathrm{pH}$ values were generally below 2.8 . Thus, OS formation would obviously be promoted as the increasing of acidic sulfate aerosols, aerosol acidity, and LWC. When SIA accumulation was dominated by nitrate $\left(\mathrm{SO}_{4}^{2-} / \mathrm{SIA}<0.5\right)$, high aerosol LWC may occur, while the OS formation via acid-catalyzed reactions may be limited by relatively lower aerosol acidity.

The $\mathrm{NO}_{3}$-initiated oxidation dominated the nighttime BVOC loss in summertime Beijing, with $\mathrm{NO}_{x}$ / BVOCs ratios higher than 10 at night. Significant nighttime enhancement of monoterpene NOSs was observed, indicating formation via the $\mathrm{NO}_{3}$-initiated oxidation of monoterpene under high- $\mathrm{NO}_{x}$ conditions. Higher concentrations of monoterpene NOSs were found with elevated $\mathrm{NO}_{2}$ levels at night and $\mathrm{NO}_{2}$ ceased to be a limiting factor for NOS formation when higher than $20 \mathrm{ppb}$. The lower daytime concentrations of monoterpene NOSs could be attributed to lower production and decomposition during daytime. In contrast to monoterpene NOS formation via $\mathrm{NO}_{3}$-initiated oxidation, isoprene NOSs and OSs are presumed to form via acid-catalyzed chemistry or reactive uptake of the oxidation products of isoprene, which needs to be further investigated through laboratory studies. The daytime $\mathrm{NO}_{2}$ concentration could be a limiting factor for isoprene NOS formation, while nighttime formation was limited by isoprene or its oxidation products. The proposed formation mechanisms of isoprene NOSs as well as the limiting factors still need further investigation in laboratory studies.

This study highlights the formation of OSs and NOSs via the interaction between biogenic VOC precursors and an- thropogenic pollutants $\left(\mathrm{NO}_{x}, \mathrm{SO}_{2}\right.$, and $\left.\mathrm{SO}_{4}^{2-}\right)$ in summer in Beijing. Our study reveals the accumulation of OSs with an increase in acidic sulfate aerosols and the nighttime enhancement of monoterpene NOSs under high- $\mathrm{NO}_{x}$ conditions. Acidic sulfate aerosols and high nighttime $\mathrm{NO}_{x}$ or $\mathrm{N}_{2} \mathrm{O}_{5}$ concentrations were observed in Beijing in our observation and also other studies (Liu et al., 2017; Wang et al., 2017a, b), which provide favorable conditions for the formation of OSs and NOSs. The results imply the importance of reducing anthropogenic emissions, especially $\mathrm{NO}_{x}$ and $\mathrm{SO}_{2}$, to reduce the biogenic SOA burden in Beijing and also in areas with abundant biogenic emissions and anthropogenic pollutants. Moreover, OSs or NOSs could be treated as key SOA species when exploring biogenic-anthropogenic interactions as well as organic-inorganic reactions.

Data availability. The data set is available upon request by contacting Min Hu (minhu@pku.edu.cn).

\section{The Supplement related to this article is available online at https://doi.org/10.5194/acp-18-10693-2018- supplement.}

Author contributions. MiH, MaH, and SG organized the field campaign. YJW and YCW conducted the offline analysis and analyzed the data. YJW wrote the paper with input from JY. All authors contributed to measurements, discussing results, and commenting on the paper.

Competing interests. The authors declare that they have no conflict of interest.

Acknowledgements. This work was supported by the National Natural Science Foundation of China (91544214, 41421064, $51636003)$, the national research program for key issues in air pollution control (DQGG0103), the National Key Research and Development Program of China (2016YFC0202000: Task 3), and the bilateral Sweden-China framework program "Photochemical smog in China: formation, transformation, impact and abatement strategies" (639-2013-6917).

Edited by: Jason Surratt

Reviewed by: four anonymous referees

\section{References}

Agarwal, S., Aggarwal, S. G., Okuzawa, K., and Kawamura, K.: Size distributions of dicarboxylic acids, ketoacids, $\alpha$ dicarbonyls, sugars, WSOC, OC, EC and inorganic ions in atmospheric particles over Northern Japan: implication for long-range transport of Siberian biomass burning and East 
Asian polluted aerosols, Atmos. Chem. Phys., 10, 5839-5858, https://doi.org/10.5194/acp-10-5839-2010, 2010.

Atkinson, R., Baulch, D. L., Cox, R. A., Crowley, J. N., Hampson, R. F., Hynes, R. G., Jenkin, M. E., Rossi, M. J., Troe, J., and IUPAC Subcommittee: Evaluated kinetic and photochemical data for atmospheric chemistry: Volume II - gas phase reactions of organic species, Atmos. Chem. Phys., 6, 3625-4055, https://doi.org/10.5194/acp-6-3625-2006, 2006.

Bikkina, S., Kawamura, K., and Sarin, M.: Secondary Organic Aerosol Formation over Coastal Ocean: Inferences from Atmospheric Water-Soluble Low Molecular Weight Organic Compounds, Environ. Sci. Technol., 51, 4347-4357, https://doi.org/10.1021/acs.est.6b05986, 2017.

Blair, S. L., MacMillan, A. C., Drozd, G. T., Goldstein, A. H., Chu, R. K., Pasa-Tolic, L., Shaw, J. B., Tolic, N., Lin, P., Laskin, J., Laskin, A., and Nizkorodov, S. A.: Molecular Characterization of Organosulfur Compounds in Biodiesel and Diesel Fuel Secondary Organic Aerosol, Environ. Sci. Technol., 51, 119-127, https://doi.org/10.1021/acs.est.6b03304, 2017.

Booth, A. M., Murphy, B., Riipinen, I., Percival, C. J., and Topping, D. O.: Connecting bulk viscosity measurements to kinetic limitations on attaining equilibrium for a model aerosol composition, Environ. Sci. Technol., 48, 9298-9305, https://doi.org/10.1021/es501705c, 2014.

Boreddy, S. K. R., Kawamura, K., and Tachibana, E.: Long-term (2001-2013) observations of water-soluble dicarboxylic acids and related compounds over the western North Pacific: trends, seasonality and source apportionment, Sci. Rep.-UK, 7, 8518, https://doi.org/10.1038/s41598-017-08745-w, 2017.

Brüggemann, M., Poulain, L., Held, A., Stelzer, T., Zuth, C., Richters, S., Mutzel, A., van Pinxteren, D., Inuma, Y., Katkevica, S., Rabe, R., Herrmann, H., and Hoffmann, T.: Realtime detection of highly oxidized organosulfates and BSOA marker compounds during the F-BEACh 2014 field study, Atmos. Chem. Phys., 17, 1453-1469, https://doi.org/10.5194/acp17-1453-2017, 2017.

Budisulistiorini, S. H., Li, X., Bairai, S. T., Renfro, J., Liu, Y., Liu, Y. J., McKinney, K. A., Martin, S. T., McNeill, V. F., Pye, H. O. T., Nenes, A., Neff, M. E., Stone, E. A., Mueller, S., Knote, C., Shaw, S. L., Zhang, Z., Gold, A., and Surratt, J. D.: Examining the effects of anthropogenic emissions on isoprenederived secondary organic aerosol formation during the 2013 Southern Oxidant and Aerosol Study (SOAS) at the Look Rock, Tennessee ground site, Atmos. Chem. Phys., 15, 8871-8888, https://doi.org/10.5194/acp-15-8871-2015, 2015.

Carlton, A. G., Wiedinmyer, C., and Kroll, J. H.: A review of Secondary Organic Aerosol (SOA) formation from isoprene, Atmos. Chem. Phys., 9, 4987-5005, https://doi.org/10.5194/acp-9-49872009, 2009.

Chan, M. N. and Chan, C. K.: Mass transfer effects in hygroscopic measurements of aerosol particles, Atmos. Chem. Phys., 5, 2703-2712, https://doi.org/10.5194/acp-5-2703-2005, 2005.

Chan, M. N., Surratt, J. D., Claeys, M., Edgerton, E. S., Tanner, R. L., Shaw, S. L., Zheng, M., Knipping, E. M., Eddingsaas, N. C., Wennberg, P. O., and Seinfeld, J. H.: Characterization and quantification of isoprene-derived epoxydiols in ambient aerosol in the southeastern United States, Environ. Sci. Technol., 44, 45904596, https://doi.org/10.1021/es100596b, 2010.
Chan, M. N., Surratt, J. D., Chan, A. W. H., Schilling, K., Offenberg, J. H., Lewandowski, M., Edney, E. O., Kleindienst, T. E., Jaoui, M., Edgerton, E. S., Tanner, R. L., Shaw, S. L., Zheng, M., Knipping, E. M., and Seinfeld, J. H.: Influence of aerosol acidity on the chemical composition of secondary organic aerosol from $\beta$-caryophyllene, Atmos. Chem. Phys., 11, 1735-1751, https://doi.org/10.5194/acp-11-1735-2011, 2011.

Charbouillot, T., Gorini, S., Voyard, G., Parazols, M., Brigante, M., Deguillaume, L., Delort, A.-M., and Mailhot, G.: Mechanism of carboxylic acid photooxidation in atmospheric aqueous phase: Formation, fate and reactivity, Atmos. Environ., 56, 1-8, https://doi.org/10.1016/j.atmosenv.2012.03.079, 2012.

Chebbi, A. and Carlier, P.: Carboxylic acids in the troposphere, occurrence, sources, and sinks: A review, Atmos. Environ., 30, 4233-4249, https://doi.org/10.1016/1352-2310(96)00102-1, 1996.

Darer, A. I., Cole-Filipiak, N. C., O'Connor, A. E., and Elrod, M. J.: Formation and stability of atmospherically relevant isoprenederived organosulfates and organonitrates, Environ. Sci. Technol., 45, 1895-1902, https://doi.org/10.1021/es103797z, 2011.

Deshmukh, D. K., Kawamura, K., Deb, M. K., and Boreddy, S. K. R.: Sources and formation processes of water-soluble dicarboxylic acids, $\omega$-oxocarboxylic acids, $\alpha$-dicarbonyls, and major ions in summer aerosols from eastern central India, J. Geophys. Res.-Atmos., 122, 3630-3652, https://doi.org/10.1002/2016jd026246, 2017.

Duporte, G., Flaud, P. M., Geneste, E., Augagneur, S., Pangui, E., Lamkaddam, H., Gratien, A., Doussin, J. F., Budzinski, H., Villenave, E., and Perraudin, E.: Experimental Study of the Formation of Organosulfates from $\alpha$-Pinene Oxidation. Part I: Product Identification, Formation Mechanisms and Effect of Relative Humidity, J. Phys. Chem. A, 120, 7909-7923, https://doi.org/10.1021/acs.jpca.6b08504, 2016.

Edwards, P. M., Aikin, K. C., Dube, W. P., Fry, J. L., Gilman, J. B., de Gouw, J. A., Graus, M. G., Hanisco, T. F., Holloway, J., Huber, G., Kaiser, J., Keutsch, F. N., Lerner, B. M., Neuman, J. A., Parrish, D. D., Peischl, J., Pollack, I. B., Ravishankara, A. R., Roberts, J. M., Ryerson, T. B., Trainer, M., Veres, P. R., Wolfe, G. M., Warneke, C., and Brown, S. S.: Transition from high- to low-NOx control of night-time oxidation in the southeastern US, Nat. Geosci., 10, 490-495, https://doi.org/10.1038/NGEO2976, 2017.

Frossard, A. A., Shaw, P. M., Russell, L. M., Kroll, J. H., Canagaratna, M. R., Worsnop, D. R., Quinn, P. K., and Bates, T. S.: Springtime Arctic haze contributions of submicron organic particles from European and Asian combustion sources, J. Geophys. Res.-Atmos., 116, D05205, https://doi.org/10.1029/2010jd015178, 2011.

Froyd, K. D., Murphy, S. M., Murphy, D. M., de Gouw, J. A., Eddingsaas, N. C., and Wennberg, P. O.: Contribution of isoprene-derived organosulfates to free tropospheric aerosol mass, P. Natl. Acad. Sci. USA, 107, 21360-21365, https://doi.org/10.1073/pnas.1012561107, 2010.

Fu, T.-M., Jacob, D. J., Wittrock, F., Burrows, J. P., Vrekoussis, M., and Henze, D. K.: Global budgets of atmospheric glyoxal and methylglyoxal, and implications for formation of secondary organic aerosols, J. Geophys. Res., 113, D15303, https://doi.org/10.1029/2007jd009505, 2008. 
Gao, S., Surratt, J. D., Knipping, E. M., Edgerton, E. S., Shahgholi, M., and Seinfeld, J. H.: Characterization of polar organic components in fine aerosols in the southeastern United States: Identity, origin, and evolution, J. Geophys. Res., 111, D14314, https://doi.org/10.1029/2005jd006601, 2006.

Gómez-González, Y., Wang, W., Vermeylen, R., Chi, X., Neirynck, J., Janssens, I. A., Maenhaut, W., and Claeys, M.: Chemical characterisation of atmospheric aerosols during a 2007 summer field campaign at Brasschaat, Belgium: sources and source processes of biogenic secondary organic aerosol, Atmos. Chem. Phys., 12, 125-138, https://doi.org/10.5194/acp-12-125-2012, 2012.

Gomez-Gonzalez, Y., Surratt, J. D., Cuyckens, F., Szmigielski, R., Vermeylen, R., Jaoui, M., Lewandowski, M., Offenberg, J. H., Kleindienst, T. E., Edney, E. O., Blockhuys, F., Van Alsenoy, C., Maenhaut, W., and Claeys, M.: Characterization of organosulfates from the photooxidation of isoprene and unsaturated fatty acids in ambient aerosol using liquid chromatography/(-) electrospray ionization mass spectrometry, J. Mass Spectrom., 43, 371-382, https://doi.org/10.1002/jms.1329, 2008.

Guo, H., Xu, L., Bougiatioti, A., Cerully, K. M., Capps, S. L., Hite Jr., J. R., Carlton, A. G., Lee, S.-H., Bergin, M. H., Ng, N. L., Nenes, A., and Weber, R. J.: Fine-particle water and $\mathrm{pH}$ in the southeastern United States, Atmos. Chem. Phys., 15, 5211-5228, https://doi.org/10.5194/acp-15-5211-2015, 2015.

Guo, H., Sullivan, A. P., Campuzano-Jost, P., Schroder, J. C., LopezHilfiker, F. D., Dibb, J. E., Jimenez, J. L., Thornton, J. A., Brown, S. S., Nenes, A., and Weber, R. J.: Particle pH and the Partitioning of Nitric Acid during Winter in the Northeastern United States, J. Geophys. Res.-Atmos., 121, 10355-10376, https://doi.org/10.1002/2016JD025311, 2016.

Guo, S., Hu, M., Wang, Z. B., Slanina, J., and Zhao, Y. L.: Sizeresolved aerosol water-soluble ionic compositions in the summer of Beijing: implication of regional secondary formation, Atmos. Chem. Phys., 10, 947-959, https://doi.org/10.5194/acp-10-9472010, 2010.

Guo, S., Hu, M., Zamora, M. L., Peng, J., Shang, D., Zheng, J., Du, Z., Wu, Z., Shao, M., Zeng, L., Molina, M. J., and Zhang, R.: Elucidating severe urban haze formation in China, P. Natl. Acad. Sci. USA, 111, 17373-17378, https://doi.org/10.1073/pnas.1419604111, 2014.

Hallquist, M., Wenger, J. C., Baltensperger, U., Rudich, Y., Simpson, D., Claeys, M., Dommen, J., Donahue, N. M., George, C., Goldstein, A. H., Hamilton, J. F., Herrmann, H., Hoffmann, T., Iinuma, Y., Jang, M., Jenkin, M. E., Jimenez, J. L., Kiendler-Scharr, A., Maenhaut, W., McFiggans, G., Mentel, Th. F., Monod, A., Prévôt, A. S. H., Seinfeld, J. H., Surratt, J. D., Szmigielski, R., and Wildt, J.: The formation, properties and impact of secondary organic aerosol: current and emerging issues, Atmos. Chem. Phys., 9, 5155-5236, https://doi.org/10.5194/acp9-5155-2009, 2009.

Hallquist, M., Munthe, J., Hu, M., Wang, T., Chan, C. K., Gao, J., Boman, J., Guo, S., Hallquist, A. M., Mellqvist, J., Moldanova, J., Pathak, R. K., Pettersson, J. B. C., Pleijel, H., Simpson, D., and Thynell, M.: Photochemical smog in China: scientific challenges and implications for air-quality policies, Natl. Sci. Rev., 3, 401-403, https://doi.org/10.1093/nsr/nww080, 2016.

Hatch, L. E., Creamean, J. M., Ault, A. P., Surratt, J. D., Chan, M. N., Seinfeld, J. H., Edgerton, E. S., Su, Y., and Prather, K. A.: Measurements of isoprene-derived organosulfates in ambient aerosols by aerosol time-of-flight mass spectrometry-part 2: temporal variability and formation mechanisms, Environ. Sci. Technol., 45, 8648-8655, https://doi.org/10.1021/es2011836, 2011.

Hawkins, L. N., Russell, L. M., Covert, D. S., Quinn, P. K., and Bates, T. S.: Carboxylic acids, sulfates, and organosulfates in processed continental organic aerosol over the southeast Pacific Ocean during VOCALS-REx 2008, J. Geophys. Res.-Atmos., 115, D13201, https://doi.org/10.1029/2009jd013276, 2010.

He, Q. F., Ding, X., Wang, X. M., Yu, J. Z., Fu, X. X., Liu, T. Y., Zhang, Z., Xue, J., Chen, D. H., Zhong, L. J., and Donahue, N. M.: Organosulfates from pinene and isoprene over the Pearl River Delta, South China: seasonal variation and implication in formation mechanisms, Environ. Sci. Technol., 48, 9236-9245, https://doi.org/10.1021/es501299v, 2014.

He, S., Chen, Z., and Zhang, X.: Photochemical reactions of methyl and ethyl nitrate: a dual role for alkyl nitrates in the nitrogen cycle, Environ. Chem., 8, 529-542, https://doi.org/10.1071/en10004, 2011.

Hennigan, C. J., Izumi, J., Sullivan, A. P., Weber, R. J., and Nenes, A.: A critical evaluation of proxy methods used to estimate the acidity of atmospheric particles, Atmos. Chem. Phys., 15, 27752790, https://doi.org/10.5194/acp-15-2775-2015, 2015.

Herndon, S. C., Onasch, T. B., Wood, E. C., Kroll, J. H., Canagaratna, M. R., Jayne, J. T., Zavala, M. A., Knighton, W. B., Mazzoleni, C., Dubey, M. K., Ulbrich, I. M., Jimenez, J. L., Seila, R., de Gouw, J. A., de Foy, B., Fast, J., Molina, L. T., Kolb, C. E., and Worsnop, D. R.: Correlation of secondary organic aerosol with odd oxygen in Mexico City, Geophys. Res. Lett., 35, L15804, https://doi.org/10.1029/2008gl034058, 2008.

Hettiyadura, A. P. S., Stone, E. A., Kundu, S., Baker, Z., Geddes, E., Richards, K., and Humphry, T.: Determination of atmospheric organosulfates using HILIC chromatography with MS detection, Atmos. Meas. Tech., 8, 2347-2358, https://doi.org/10.5194/amt8-2347-2015, 2015.

Hettiyadura, A. P. S., Jayarathne, T., Baumann, K., Goldstein, A. H., de Gouw, J. A., Koss, A., Keutsch, F. N., Skog, K., and Stone, E. A.: Qualitative and quantitative analysis of atmospheric organosulfates in Centreville, Alabama, Atmos. Chem. Phys., 17, 1343-1359, https://doi.org/10.5194/acp-17-1343-2017, 2017.

Hu, K. S., Darer, A. I., and Elrod, M. J.: Thermodynamics and kinetics of the hydrolysis of atmospherically relevant organonitrates and organosulfates, Atmos. Chem. Phys., 11, 8307-8320, https://doi.org/10.5194/acp-11-8307-2011, 2011.

Huo, Q., Cai, X., Kang, L., Zhang, H., Song, Y., and Zhu, T.: Estimating ammonia emissions from a winter wheat cropland in North China Plain with field experiments and inverse dispersion modeling, Atmos. Environ., 104, 1-10, https://doi.org/10.1016/j.atmosenv.2015.01.003, 2015.

Hu, W. W., Campuzano-Jost, P., Palm, B. B., Day, D. A., Ortega, A. M., Hayes, P. L., Krechmer, J. E., Chen, Q., Kuwata, M., Liu, Y. J., de Sá, S. S., McKinney, K., Martin, S. T., Hu, M., Budisulistiorini, S. H., Riva, M., Surratt, J. D., St. Clair, J. M., Isaacman-Van Wertz, G., Yee, L. D., Goldstein, A. H., Carbone, S., Brito, J., Artaxo, P., de Gouw, J. A., Koss, A., Wisthaler, A., Mikoviny, T., Karl, T., Kaser, L., Jud, W., Hansel, A., Docherty, K. S., Alexander, M. L., Robinson, N. H., Coe, H., Allan, J. D., Canagaratna, M. R., Paulot, F., and Jimenez, J. L.: Characterization of a real-time tracer for isoprene epoxydiols-derived secondary organic aerosol (IEPOX-SOA) from aerosol mass spec- 
trometer measurements, Atmos. Chem. Phys., 15, 11807-11833, https://doi.org/10.5194/acp-15-11807-2015, 2015.

Iinuma, Y., Muller, C., Berndt, T., Boge, O., Claeys, M., and Herrmann, H.: Evidence for the existence of organosulfates from $\beta$-pinene ozonolysis in ambient secondary organic aerosol, Environ. Sci. Technol., 41, 6678-6683, https://doi.org/10.1021/es070938t, 2007.

Jimenez, J. L., Canagaratna, M. R., Donahue, N. M., Prevot, A. S., Zhang, Q., Kroll, J. H., DeCarlo, P. F., Allan, J. D., Coe, H., Ng, N. L., Aiken, A. C., Docherty, K. S., Ulbrich, I. M., Grieshop, A. P., Robinson, A. L., Duplissy, J., Smith, J. D., Wilson, K. R., Lanz, V. A., Hueglin, C., Sun, Y. L., Tian, J., Laaksonen, A., Raatikainen, T., Rautiainen, J., Vaattovaara, P., Ehn, M., Kulmala, M., Tomlinson, J. M., Collins, D. R., Cubison, M. J., Dunlea, E. J., Huffman, J. A., Onasch, T. B., Alfarra, M. R., Williams, P. I., Bower, K., Kondo, Y., Schneider, J., Drewnick, F., Borrmann, S., Weimer, S., Demerjian, K., Salcedo, D., Cottrell, L., Griffin, R., Takami, A., Miyoshi, T., Hatakeyama, S., Shimono, A., Sun, J. Y., Zhang, Y. M., Dzepina, K., Kimmel, J. R., Sueper, D., Jayne, J. T., Herndon, S. C., Trimborn, A. M., Williams, L. R., Wood, E. C., Middlebrook, A. M., Kolb, C. E., Baltensperger, U., and Worsnop, D. R.: Evolution of organic aerosols in the atmosphere, Science, 326, 1525-1529, https://doi.org/10.1126/science.1180353, 2009.

Kawamura, K., Kasukabe, H., and Barrie, L. A.: Secondary formation of water-soluble organic acids and $\alpha$-dicarbonyls and their contributions to total carbon and water-soluble organic carbon: Photochemical aging of organic aerosols in the Arctic spring, J. Geophys. Res., 115, D21306, https://doi.org/10.1029/2010jd014299, 2010.

Kiehl, J. T.: Twentieth century climate model response and climate sensitivity, Geophys. Res. Lett., 34, L22710, https://doi.org/10.1029/2007gl031383, 2007.

Kroll, J. H. and Seinfeld, J. H.: Chemistry of secondary organic aerosol: Formation and evolution of low-volatility organics in the atmosphere, Atmos. Environ., 42, 3593-3624, https://doi.org/10.1016/j.atmosenv.2008.01.003, 2008.

Lal, V., Khalizov, A. F., Lin, Y., Galvan, M. D., Connell, B. T., and Zhang, R.: Heterogeneous reactions of epoxides in acidic media, J. Phys. Chem. A, 116, 6078-6090, https://doi.org/10.1021/jp2112704, 2012.

Lee, B. H., Mohr, C., Lopez-Hilfiker, F. D., Lutz, A., Hallquist, M., Lee, L., Romer, P., Cohen, R. C., Iyer, S., Kurten, T., Hu, W., Day, D. A., Campuzano-Jost, P., Jimenez, J. L., Xu, L., Ng, N. L., Guo, H., Weber, R. J., Wild, R. J., Brown, S. S., Koss, A., de Gouw, J., Olson, K., Goldstein, A. H., Seco, R., Kim, S., McAvey, K., Shepson, P. B., Starn, T., Baumann, K., Edgerton, E. S., Liu, J., Shilling, J. E., Miller, D. O., Brune, W., Schobesberger, S., D'Ambro, E. L., and Thornton, J. A.: Highly functionalized organic nitrates in the southeast United States: Contribution to secondary organic aerosol and reactive nitrogen budgets, P. Natl. Acad. Sci. USA, 113, 1516-1521, https://doi.org/10.1073/pnas.1508108113, 2016.

Li, W., Sun, J., Xu, L., Shi, Z., Riemer, N., Sun, Y., Fu, P., Zhang, J., Lin, Y., Wang, X., Shao, L., Chen, J., Zhang, X., Wang, Z., and Wang, W.: A conceptual framework for mixing structures in individual aerosol particles, J. Geophys. Res.-Atmos., 121, 1378413798, https://doi.org/10.1002/2016jd025252, 2016.
Liao, J., Froyd, K. D., Murphy, D. M., Keutsch, F. N., Yu, G., Wennberg, P. O., St Clair, J. M., Crounse, J. D., Wisthaler, A., Mikoviny, T., Jimenez, J. L., Campuzano-Jost, P., Day, D. A., Hu, W., Ryerson, T. B., Pollack, I. B., Peischl, J., Anderson, B. E., Ziemba, L. D., Blake, D. R., Meinardi, S., and Diskin, G.: Airborne measurements of organosulfates over the continental U.S, J. Geophys. Res.-Atmos., 120, 2990-3005, https://doi.org/10.1002/2014JD022378, 2015.

Liggio, J. and Li, S.-M.: Organosulfate formation during the uptake of pinonaldehyde on acidic sulfate aerosols, Geophys. Res. Lett., 33, L13808, https://doi.org/10.1029/2006gl026079, 2006.

Lin, P., Huang, X. F., He, L. Y., and Yu, J. Z.: Abundance and size distribution of HULIS in ambient aerosols at a rural site in South China, J. Aerosol Sci., 41, 74-87, https://doi.org/10.1016/j.jaerosci.2009.09.001, 2010.

Lin, P., Yu, J. Z., Engling, G., and Kalberer, M.: Organosulfates in humic-like substance fraction isolated from aerosols at seven locations in East Asia: a study by ultra-high-resolution mass spectrometry, Environ. Sci. Technol., 46, 13118-13127, https://doi.org/10.1021/es303570v, 2012.

Lin, Y.-H., Knipping, E. M., Edgerton, E. S., Shaw, S. L., and Surratt, J. D.: Investigating the influences of $\mathrm{SO}_{2}$ and $\mathrm{NH}_{3}$ levels on isoprene-derived secondary organic aerosol formation using conditional sampling approaches, Atmos. Chem. Phys., 13, 84578470, https://doi.org/10.5194/acp-13-8457-2013, 2013a.

Lin, Y. H., Zhang, H., Pye, H. O., Zhang, Z., Marth, W. J., Park, S., Arashiro, M., Cui, T., Budisulistiorini, S. H., Sexton, K. G., Vizuete, W., Xie, Y., Luecken, D. J., Piletic, I. R., Edney, E. O., Bartolotti, L. J., Gold, A., and Surratt, J. D.: Epoxide as a precursor to secondary organic aerosol formation from isoprene photooxidation in the presence of nitrogen oxides, P. Natl. Acad. Sci. USA, 110, 6718-6723, https://doi.org/10.1073/pnas.1221150110, 2013b.

Liu, M., Song, Y., Zhou, T., Xu, Z., Yan, C., Zheng, M., Wu, Z., $\mathrm{Hu}, \mathrm{M}$., Wu, Y., and Zhu, T.: Fine particle $\mathrm{pH}$ during severe haze episodes in northern China, Geophys. Res. Lett., 44, 5213-5221, https://doi.org/10.1002/2017gl073210, 2017.

Ma, Y., Xu, X. K., Song, W. H., Geng, F. H., and Wang, L.: Seasonal and diurnal variations of particulate organosulfates in urban Shanghai, China, Atmos. Environ., 85, 152-160, https://doi.org/10.1016/j.atmosenv.2013.12.017, 2014.

McNeill, V. F.: Aqueous organic chemistry in the atmosphere: sources and chemical processing of organic aerosols, Environ. Sci. Technol., 49, 1237-1244, https://doi.org/10.1021/es5043707, 2015.

McNeill, V. F., Woo, J. L., Kim, D. D., Schwier, A. N., Wannell, N. J., Sumner, A. J., and Barakat, J. M.: Aqueous-phase secondary organic aerosol and organosulfate formation in atmospheric aerosols: a modeling study, Environ. Sci. Technol., 46, 8075-8081, https://doi.org/10.1021/es3002986, 2012.

Meade, L. E., Riva, M., Blomberg, M. Z., Brock, A. K., Qualters, E. M., Siejack, R. A., Ramakrishnan, K., Surratt, J. D., and Kautzman, K. E.: Seasonal variations of fine particulate organosulfates derived from biogenic and anthropogenic hydrocarbons in the mid-Atlantic United States, Atmos. Environ., 145, 405-414, https://doi.org/10.1016/j.atmosenv.2016.09.028, 2016.

Minerath, E. C. and Elrod, M. J.: Assessing the potential for diol and hydroxy sulfate ester formation from the reaction of epoxides 
in tropospheric aerosols, Environ. Sci. Technol., 43, 1386-1392, https://doi.org/10.1021/es8029076, 2009.

Minerath, E. C., Casale, M. T., and Elrod, M. J.: Kinetics Feasibility Study of Alcohol Sulfate Esterification Reactions in Tropospheric Aerosols, Environ. Sci. Technol., 42, 4410-4415, https://doi.org/10.1021/es8004333, 2008.

Narukawa, M.: Fine and coarse modes of dicarboxylic acids in the Arctic aerosols collected during the Polar Sunrise Experiment 1997, J. Geophys. Res., 108, 4575, https://doi.org/10.1029/2003jd003646, 2003.

Nguyen, T. B., Bates, K. H., Crounse, J. D., Schwantes, R. H., Zhang, X., Kjaergaard, H. G., Surratt, J. D., Lin, P., Laskin, A., Seinfeld, J. H., and Wennberg, P. O.: Mechanism of the hydroxyl radical oxidation of methacryloyl peroxynitrate (MPAN) and its pathway toward secondary organic aerosol formation in the atmosphere, Phys. Chem. Chem. Phys., 17, 17914-17926, https://doi.org/10.1039/c5cp02001h, 2015.

Nozière, B., Ekström, S., Alsberg, T., and Holmström, S.: Radical-initiated formation of organosulfates and surfactants in atmospheric aerosols, Geophys. Res. Lett., 37, L05806, https://doi.org/10.1029/2009g1041683, 2010.

Olson, C. N., Galloway, M. M., Yu, G., Hedman, C. J., Lockett, M. R., Yoon, T., Stone, E. A., Smith, L. M., and Keutsch, F. N.: Hydroxycarboxylic acid-derived organosulfates: synthesis, stability, and quantification in ambient aerosol, Environ. Sci. Technol., 45, 6468-6474, https://doi.org/10.1021/es201039p, 2011.

Paulot, F., Crounse, J. D., Kjaergaard, H. G., Kurten, A., St Clair, J. M., Seinfeld, J. H., and Wennberg, P. O.: Unexpected epoxide formation in the gas-phase photooxidation of isoprene, Science, 325, 730-733, 10.1126/science.1172910, 2009.

Rattanavaraha, W., Chu, K., Budisulistiorini, S. H., Riva, M., Lin, Y.-H., Edgerton, E. S., Baumann, K., Shaw, S. L., Guo, H., King, L., Weber, R. J., Neff, M. E., Stone, E. A., Offenberg, J. H., Zhang, Z., Gold, A., and Surratt, J. D.: Assessing the impact of anthropogenic pollution on isoprene-derived secondary organic aerosol formation in $\mathrm{PM}_{2.5}$ collected from the Birmingham, Alabama, ground site during the 2013 Southern Oxidant and Aerosol Study, Atmos. Chem. Phys., 16, 4897-4914, https://doi.org/10.5194/acp-16-4897-2016, 2016.

Renbaum-Wolff, L., Grayson, J. W., Bateman, A. P., Kuwata, M., Sellier, M., Murray, B. J., Shilling, J. E., Martin, S. T., and Bertram, A. K.: Viscosity of $\alpha$-pinene secondary organic material and implications for particle growth and reactivity, P. Natl. Acad. Sci. USA, 110, 8014-8019, https://doi.org/10.1073/pnas.1219548110, 2013.

Riedel, T. P., Lin, Y.-H., Budisulistiorini, S. H., Gaston, C. J., Thornton, J. A., Zhang, Z., Vizuete, W., Gold, A., and Surratt, J. D.: Heterogeneous Reactions of Isoprene-Derived Epoxides: Reaction Probabilities and Molar Secondary Organic Aerosol Yield Estimates, Environ. Sci. Tech. Let., 2, 38-42, https://doi.org/10.1021/ez500406f, 2015.

Riva, M., Tomaz, S., Cui, T., Lin, Y. H., Perraudin, E., Gold, A., Stone, E. A., Villenave, E., and Surratt, J. D.: Evidence for an unrecognized secondary anthropogenic source of organosulfates and sulfonates: gas-phase oxidation of polycyclic aromatic hydrocarbons in the presence of sulfate aerosol, Environ. Sci. Technol., 49, 6654-6664, https://doi.org/10.1021/acs.est.5b00836, 2015.
Riva, M., Bell, D. M., Hansen, A. M., Drozd, G. T., Zhang, Z., Gold, A., Imre, D., Surratt, J. D., Glasius, M., and Zelenyuk, A.: Effect of Organic Coatings, Humidity and Aerosol Acidity on Multiphase Chemistry of Isoprene Epoxydiols, Environ. Sci. Technol., 50, 5580-5588, https://doi.org/10.1021/acs.est.5b06050, 2016a.

Riva, M., Budisulistiorini, S. H., Zhang, Z., Gold, A., and Surratt, J. D.: Chemical characterization of secondary organic aerosol constituents from isoprene ozonolysis in the presence of acidic aerosol, Atmos. Environ., 130, 5-13, https://doi.org/10.1016/j.atmosenv.2015.06.027, 2016b.

Riva, M., Da Silva Barbosa, T., Lin, Y.-H., Stone, E. A., Gold, A., and Surratt, J. D.: Chemical characterization of organosulfates in secondary organic aerosol derived from the photooxidation of alkanes, Atmos. Chem. Phys., 16, 11001-11018, https://doi.org/10.5194/acp-16-11001-2016, $2016 \mathrm{c}$.

Schindelka, J., Iinuma, Y., Hoffmann, D., and Herrmann, H.: Sulfate radical-initiated formation of isoprene-derived organosulfates in atmospheric aerosols, Faraday Discuss., 165, 237-259, https://doi.org/10.1039/c3fd00042g, 2013.

Shalamzari, M. S., Kahnt, A., Vermeylen, R., Kleindienst, T. E., Lewandowski, M., Cuyckens, F., Maenhaut, W., and Claeys, M.: Characterization of polar organosulfates in secondary organic aerosol from the green leaf volatile 3-Z-hexenal, Environ. Sci. Technol., 48, 12671-12678, https://doi.org/10.1021/es503226b, 2014.

Shalamzari, M. S., Vermeylen, R., Blockhuys, F., Kleindienst, T. E., Lewandowski, M., Szmigielski, R., Rudzinski, K. J., Spólnik, G., Danikiewicz, W., Maenhaut, W., and Claeys, M.: Characterization of polar organosulfates in secondary organic aerosol from the unsaturated aldehydes 2-E-pentenal, 2-Ehexenal, and 3-Z-hexenal, Atmos. Chem. Phys., 16, 7135-7148, https://doi.org/10.5194/acp-16-7135-2016, 2016.

Shiraiwa, M., Ammann, M., Koop, T., and Pöschl, U.: Gas uptake and chemical aging of semisolid organic aerosol particles, P. Natl. Acad. Sci. USA, 108, 11003-11008, https://doi.org/10.1073/pnas.1103045108, 2011.

Shrestha, M., Zhang, Y., Upshur, M. A., Liu, P., Blair, S. L., Wang, H. F., Nizkorodov, S. A., Thomson, R. J., Martin, S. T., and Geiger, F. M.: On surface order and disorder of alpha-pinenederived secondary organic material, J. Phys. Chem. A, 119, 4609-4617, https://doi.org/10.1021/jp510780e, 2015.

Shrivastava, M., Cappa, C. D., Fan, J., Goldstein, A. H., Guenther, A. B., Jimenez, J. L., Kuang, C., Laskin, A., Martin, S. T., Ng, N. L., Petaja, T., Pierce, J. R., Rasch, P. J., Roldin, P., Seinfeld, J. H., Shilling, J., Smith, J. N., Thornton, J. A., Volkamer, R., Wang, J., Worsnop, D. R., Zaveri, R. A., Zelenyuk, A., and Zhang, Q.: Recent advances in understanding secondary organic aerosol: Implications for global climate forcing, Rev. Geophys., 55, 509559, https://doi.org/10.1002/2016rg000540, 2017.

Staudt, S., Kundu, S., Lehmler, H. J., He, X., Cui, T., Lin, Y. H., Kristensen, K., Glasius, M., Zhang, X., Weber, R. J., Surratt, J. D., and Stone, E. A.: Aromatic organosulfates in atmospheric aerosols: synthesis, characterization, and abundance, Atmos. Environ., 94, 366-373, https://doi.org/10.1016/j.atmosenv.2014.05.049, 2014.

Stone, E. A., Yang, L., Yu, L. E., and Rupakheti, M.: Characterization of organosulfates in atmospheric aerosols at Four Asian locations, Atmos. Environ., 47, 323-329, https://doi.org/10.1016/j.atmosenv.2011.10.058, 2012. 
Suarez-Bertoa, R., Picquet-Varrault, B., Tamas, W., Pangui, E., and Doussin, J. F.: Atmospheric fate of a series of carbonyl nitrates: photolysis frequencies and $\mathrm{OH}$-oxidation rate constants, Environ. Sci. Technol., 46, 12502-12509, https://doi.org/10.1021/es302613x, 2012.

Surratt, J. D., Kroll, J. H., Kleindienst, T. E., Edney, E. O., Claeys, M., Sorooshian, A., Ng, N. L., Offenberg, J. H., Lewandowski, M., Jaoui, M., Flagan, R. C., and Seinfeld, J. H.: Evidence for Organosulfates in Secondary Organic Aerosol, Environ. Sci. Technol., 41, 517-527, https://doi.org/10.1021/es062081q, 2007.

Surratt, J. D., Gomez-Gonzalez, Y., Chan, A. W., Vermeylen, R., Shahgholi, M., Kleindienst, T. E., Edney, E. O., Offenberg, J. H., Lewandowski, M., Jaoui, M., Maenhaut, W., Claeys, M., Flagan, R. C., and Seinfeld, J. H.: Organosulfate formation in biogenic secondary organic aerosol, J. Phys. Chem. A, 112, 8345-8378, https://doi.org/10.1021/jp802310p, 2008.

Surratt, J. D., Chan, A. W., Eddingsaas, N. C., Chan, M., Loza, C. L., Kwan, A. J., Hersey, S. P., Flagan, R. C., Wennberg, P. O., and Seinfeld, J. H.: Reactive intermediates revealed in secondary organic aerosol formation from isoprene, P. Natl. Acad. Sci. USA, 107, 6640-6645, https://doi.org/10.1073/pnas.0911114107, 2010.

Tang, R., Wu, Z., Li, X., Wang, Y., Shang, D., Xiao, Y., Li, M., Zeng, L., Wu, Z., Hallquist, M., Hu, M., and Guo, S.: Primary and secondary organic aerosols in summer 2016 in Beijing, Atmos. Chem. Phys., 18, 4055-4068, https://doi.org/10.5194/acp18-4055-2018, 2018.

Tao, S., Lu, X., Levac, N., Bateman, A. P., Nguyen, T. B., Bones, D. L., Nizkorodov, S. A., Laskin, J., Laskin, A., and Yang, X.: Molecular characterization of organosulfates in organic aerosols from Shanghai and Los Angeles urban areas by nanospray-desorption electrospray ionization high-resolution mass spectrometry, Environ. Sci. Technol., 48, 10993-11001, https://doi.org/10.1021/es5024674, 2014.

Tolocka, M. P. and Turpin, B.: Contribution of organosulfur compounds to organic aerosol mass, Environ. Sci. Technol., 46, 7978-7983, https://doi.org/10.1021/es300651v, 2012.

Turpin, B. J. and Lim, H.-J.: Species Contributions to PM2.5 Mass Concentrations: Revisiting Common Assumptions for Estimating Organic Mass, Aerosol Sci. Tech., 35, 602-610, https://doi.org/10.1080/02786820119445, 2001.

Vaden, T. D., Imre, D., Beranek, J., Shrivastava, M., and Zelenyuk, A.: Evaporation kinetics and phase of laboratory and ambient secondary organic aerosol, P. Natl. Acad. Sci. USA, 108, 21902195, https://doi.org/10.1073/pnas.1013391108, 2011.

Wang, H., Chen, J., and Lu, K.: Development of a portable cavityenhanced absorption spectrometer for the measurement of ambient $\mathrm{NO}_{3}$ and $\mathrm{N}_{2} \mathrm{O}_{5}$ : experimental setup, lab characterizations, and field applications in a polluted urban environment, Atmos. Meas. Tech., 10, 1465-1479, https://doi.org/10.5194/amt10-1465-2017, 2017a.

Wang, H., Lu, K., Chen, X., Zhu, Q., Chen, Q., Guo, S., Jiang, M., Li, X., Shang, D., Tan, Z., Wu, Y., Wu, Z., Zou, Q., Zheng, Y., Zeng, L., Zhu, T., Hu, M., and Zhang, Y.: High $\mathrm{N}_{2} \mathrm{O}_{5}$ Concentrations Observed in Urban Beijing: Implications of a Large Nitrate Formation Pathway, Environ. Sci. Tech. Let., 4, 416-420, https://doi.org/10.1021/acs.estlett.7b00341, 2017b.

Wang, H., Lu, K., Guo, S., Wu, Z., Shang, D., Tan, Z., Wang, Y., Le Breton, M., Lou, S., Tang, M., Wu, Y., Zhu, W., Zheng, J.,
Zeng, L., Hallquist, M., Hu, M., and Zhang, Y.: Efficient $\mathrm{N}_{2} \mathrm{O}_{5}$ uptake and NO3 oxidation in the outflow of urban Beijing, Atmos. Chem. Phys., 18, 9705-9721, https://doi.org/10.5194/acp18-9705-2018, 2018.

Wang, X. K., Rossignol, S., Ma, Y., Yao, L., Wang, M. Y., Chen, J. M., George, C., and Wang, L.: Molecular characterization of atmospheric particulate organosulfates in three megacities at the middle and lower reaches of the Yangtze River, Atmos. Chem. Phys., 16, 2285-2298, https://doi.org/10.5194/acp16-2285-2016, 2016.

Wang, Y., Hu, M., Lin, P., Guo, Q., Wu, Z., Li, M., Zeng, L., Song, Y., Zeng, L., Wu, Y., Guo, S., Huang, X., and He, L.: Molecular Characterization of Nitrogen-Containing Organic Compounds in Humic-like Substances Emitted from Straw Residue Burning, Environ. Sci. Technol., 51, 5951-5961, https://doi.org/10.1021/acs.est.7b00248, 2017c.

Wang, Y., Ren, J., Huang, X. H. H., Tong, R., and Yu, J. Z.: Synthesis of Four Monoterpene-Derived Organosulfates and Their Quantification in Atmospheric Aerosol Samples, Environ. Sci. Technol., 51, 6791-6801, https://doi.org/10.1021/acs.est.7b01179, 2017d.

Weber, R. J., Guo, H., Russell, A. G., and Nenes, A.: High aerosol acidity despite declining atmospheric sulfate concentrations over the past 15 years, Nat. Geosci., 9, 282-285, https://doi.org/10.1038/ngeo2665, 2016.

Worton, D. R., Surratt, J. D., Lafranchi, B. W., Chan, A. W., Zhao, Y., Weber, R. J., Park, J. H., Gilman, J. B., de Gouw, J., Park, C., Schade, G., Beaver, M., Clair, J. M., Crounse, J., Wennberg, P., Wolfe, G. M., Harrold, S., Thornton, J. A., Farmer, D. K., Docherty, K. S., Cubison, M. J., Jimenez, J. L., Frossard, A. A., Russell, L. M., Kristensen, K., Glasius, M., Mao, J., Ren, X., Brune, W., Browne, E. C., Pusede, S. E., Cohen, R. C., Seinfeld, J. H., and Goldstein, A. H.: Observational insights into aerosol formation from isoprene, Environ. Sci. Technol., 47, 1140311413, https://doi.org/10.1021/es4011064, 2013.

Wu, Z., Wang, Y., Tan, T., Zhu, Y., Li, M., Shang, D., Wang, H., Lu, K., Guo, S., Zeng, L., and Zhang, Y.: Aerosol Liquid Water Driven by Anthropogenic Inorganic Salts: Implying Its Key Role in Haze Formation over the North China Plain, Environ. Sci. Tech. Let., 5, 160-166, https://doi.org/10.1021/acs.estlett.8b00021, 2018.

Xu, L., Guo, H., Boyd, C. M., Klein, M., Bougiatioti, A., Cerully, K., Hite, J., Wertz, G., Kreisberg, N., Knote, C., Olson, K., Koss, A., Goldstein, A., Hering, S., Gouw, J., Baumann, K., Lee, S., Nenes, A., Weber, R., and Ng, N. L: Effects of anthropogenic emissions on aerosol formation from isoprene and monoterpenes in the southeastern United States, P. Natl. Acad. Sci. USA, 112, 4506-4507, https://doi.org/10.1073/pnas.1417609112, 2015.

Xue, J., Griffith, S. M., Yu, X., Lau, A. K. H., and Yu, J. Z.: Effect of nitrate and sulfate relative abundance in $\mathrm{PM}_{2.5}$ on liquid water content explored through half-hourly observations of inorganic soluble aerosols at a polluted receptor site, Atmos. Environ., 99, 24-31, https://doi.org/10.1016/j.atmosenv.2014.09.049, 2014.

Zhang, H., Worton, D. R., Lewandowski, M., Ortega, J., Rubitschun, C. L., Park, J. H., Kristensen, K., Campuzano-Jost, P., Day, D. A., Jimenez, J. L., Jaoui, M., Offenberg, J. H., Kleindienst, T. E., Gilman, J., Kuster, W. C., de Gouw, J., Park, C., Schade, G. W., Frossard, A. A., Russell, L., Kaser, L., Jud, W., Hansel, A., Cappellin, L., Karl, T., Glasius, M., Guenther, 
A., Goldstein, A. H., Seinfeld, J. H., Gold, A., Kamens, R. M., and Surratt, J. D.: Organosulfates as tracers for secondary organic aerosol (SOA) formation from 2-methyl-3-buten-2-ol (MBO) in the atmosphere, Environ. Sci. Technol., 46, 94379446, https://doi.org/10.1021/es301648z, 2012.

Zhang, Y., Sanchez, M. S., Douet, C., Wang, Y., Bateman, A. P., Gong, Z., Kuwata, M., Renbaum-Wolff, L., Sato, B. B., Liu, P. F., Bertram, A. K., Geiger, F. M., and Martin, S. T.: Changing shapes and implied viscosities of suspended submicron particles, Atmos. Chem. Phys., 15, 7819-7829, https://doi.org/10.5194/acp15-7819-2015, 2015.

Zhang, Y., Chen, Y., Lambe, A. T., Olson, N. E., Lei, Z., Craig, R. L., Zhang, Z., Gold, A., Onasch, T. B., Jayne, J. T., Worsnop, D. R., Gaston, C. J., Thornton, J. A., Vizuete, W., Ault, A. P., and Surratt, J. D.: Effect of the Aerosol-Phase State on Secondary Organic Aerosol Formation from the Reactive Uptake of IsopreneDerived Epoxydiols (IEPOX), Environ. Sci. Tech. Let., 5, 167174, https://doi.org/10.1021/acs.estlett.8b00044, 2018.
Zhang, Y. J., Tang, L. L., Sun, Y. L., Favez, O., Canonaco, F., Albinet, A., Couvidat, F., Liu, D. T., Jayne, J. T., Wang, Z., Croteau, P. L., Canagaratna, M. R., Zhou, H. C., Prevot, A. S. H., and Worsnop, D. R.: Limited formation of isoprene epoxydiols-derived secondary organic aerosol under $\mathrm{NO}_{x}$-rich environments in Eastern China, Geophys. Res. Lett., 44, 20352043, https://doi.org/10.1002/2016GL072368, 2017.

Zheng, J., Hu, M., Du, Z., Shang, D., Gong, Z., Qin, Y., Fang, J., Gu, F., Li, M., Peng, J., Li, J., Zhang, Y., Huang, X., He, L., Wu, Y., and Guo, S.: Influence of biomass burning from South Asia at a high-altitude mountain receptor site in China, Atmos. Chem. Phys., 17, 6853-6864, https://doi.org/10.5194/acp17-6853-2017, 2017. 